\title{
TARIFF PASS-THROUGH, FIRM HETEROGENEITY AND PRODUCT QUALITY
}

\author{
by
}

\author{
Zhi George Yu * \\ Georgetown Unviersity
}

CES 10-37
October, 2010

The research program of the Center for Economic Studies (CES) produces a wide range of economic analyses to improve the statistical programs of the U.S. Census Bureau. Many of these analyses take the form of CES research papers. The papers have not undergone the review accorded Census Bureau publications and no endorsement should be inferred. Any opinions and conclusions expressed herein are those of the author(s) and do not necessarily represent the views of the U.S. Census Bureau. All results have been reviewed to ensure that no confidential information is disclosed. Republication in whole or part must be cleared with the authors.

To obtain information about the series, see www.ces.census.gov or contact Cheryl Grim, Editor, Discussion Papers, U.S. Census Bureau, Center for Economic Studies 2K130B, 4600 Silver Hill Road, Washington, DC 20233, CES.Papers.List@census.gov. 


\begin{abstract}
Previous studies on tariff pass-through were constrained at the industry level. This paper is the first attempt to explore tariff pass-through at the firm level, and to investigate how it depends on firm heterogeneity in productivity and product differentiation in quality. Using an extended version of the Melitz and Ottaviano (2008) model, I show that exporting firms absorb tariff changes by adjusting both their markups and product quality, which leads to an incomplete tariff pass-through. Moreover, tariff absorption elasticity negatively depends on firm productivity for quality differentiated goods, but positively depends on firm productivity for quality homogeneous goods. Using the U.S. transaction level export data and plant-level manufacturing data, I find evidence for these predictions. The firm-level tariff absorption elasticity is 0.87 on average. All products in the sample on average fit the definition of quality differentiated goods, and the tariff absorption elasticity is indeed higher for low productivity firms (1.27) and lower for high productivity firms (0.44). Dividing all products into quality homogeneous goods and quality differentiated goods in terms of various criteria also results in estimates consistent with model predictions for quality differentiated goods.
\end{abstract}

JEL Numbers: F1, D2, L1

* The research in this paper was conducted while the author was a Special Sworn Status researcher at the U.S. Census Bureau, Center for Economic Studies. Any opinions and conclusions expressed herein are those of the author and do not necessarily represent the views of the U.S. Census Bureau. All results have been reviewed to ensure that no confidential information is disclosed. I am very grateful to Rodney Ludema, Bradford Jensen and Anna Maria Mayda for their invaluable guidance and continuous support. I thank Antoine Gervais, Tom Holmes, William Kerr, Kala Krishna, Ben Mandel, Daniel Reyes, Justin Pierce, Cheryl Grim and participants at Georgetown International Economics Seminar, the Midwest Trade Meeting (Fall 2010), the Southern Economic Association Conference (2010), the Census RDC Annual Research Conference (2010) for helpful comments and discussions. I also thank Lynn Riggs of the Census Bureau for continuous technical support and Jim Davis of the NBER for timely disclosure of my data analysis. Support for this research at the Census Bureau RDC from NSF (ITR-0427889) is also gratefully acknowledged. 


\section{Introduction}

This paper is the first attempt to explore tariff pass-through at the firm level, and to investigate how it depends on firm heterogeneity in productivity and product differentiation in quality. Using an extended version of the Melitz and Ottaviano (2008) model, I show that exporting firms absorb tariff changes by adjusting both their markups and product quality, which leads to an incomplete tariff pass-through. Moreover, tariff absorption elasticity negatively depends on firm productivity for quality differentiated goods, but positively depends on firm productivity for quality homogeneous goods. Using the U.S. transaction-level export data and plant-level manufacturing data, I find evidence for these predictions: The firm-level tariff pass-through is indeed incomplete, and tariff absorption does depend on firm productivity and product quality as the model predicts, especially for quality differentiated goods.

This paper derives its motivation from the literature in two areas: the incompleteness of tariff pass-through, and the heterogeneous firm models of international trade. The incompleteness of tariff pass-through is the source of terms-of-trade effect of trade policies. It says that when a large country raises its tariff rate on a product, foreign exporting firms which sell in its market may absorb part of the tariff change by lowering their exporting prices ${ }^{1}$. Thus the tariff-inclusive consumer prices increase by a magnitude less than the tariff increase, and the impact of tariff change on market demand is mitigated. Tariff increase improves terms-of-trade for the home country and worsens the terms-oftrade of its trading partners. This terms-of-trade effect is the basis for the optimal tariff argument $^{2}$, from Edgeworth (1894) to Broda, Limão and Weinstein (2008), Bagwell and Staiger (2009), and Ludema and Mayda (2010).

There have been several empirical studies on the incompleteness of tariff passthrough. Feenstra (1989) finds that around 40 percent of the U.S. tariff increase in 1980s against the imports of Japanese automobiles was passed on as lower prices to Japanese

\footnotetext{
${ }^{1}$ For this reason I also refer to incomplete tariff pass-through as "tariff absorption" hereafter. Graphically, tariff-absorption is represented by the downward movement along the upward-slopping foreign export supply curve of the home country.

${ }^{2}$ The argument says that, the lower is the export supply elasticity that a country faces, the higher is the optimal tariff that the country could and would set to exploit the terms-of-trade gain.
} 
automobile exports to the U.S. Kreinin (1961) finds that more than two-thirds of U.S. tariff reductions in Geneva Round were passed on as higher prices to countries exporting to the US. Mallick and Marques (2007) find similar qualitatively results for India's trade liberalization in 1990s.

However, all the existing studies on tariff pass-through were constrained at the industry level. That is, they study how the average price of all firms in an industry responds to a tariff change ${ }^{3}$. In these studies, it was not clear whether the industrylevel price response to tariff change is caused by the intra-industry reallocation between firms with different prices, or the firm-level price change due to cost change or markup adjustment. Feenstra (1989) controls for the marginal cost of production in his estimation of the tariff pass-through elasticity. However, it is still not clear whether the industry-level price change is caused by firm-level markup adjustment or intra-industry reallocation. ${ }^{4}$ Thus firm-level studies are needed to investigate this.

For this purpose, I turn to the second literature relevant to this paper - heterogeneous firm models of international trade, since these models focus on the intra-industry reallocation between firms. Heterogeneous firm models were spurred by empirical studies, beginning with Bernard and Jensen $(1995)^{5}$, which use plant or firm-level data to document that exporting firms are on average larger and more productive than non-exporting firms. These models are characterized by firm heterogeneity in productivity, and focus on the intra-industry reallocation between firms caused by changes in trade environment. The representative models include Melitz (2003) and Bernard, Eaton, Jensen, and Kortum (2003). Melitz (2003) shows the exposure to trade induces the more productive firms to enter the export market, some less productive firms produce only for domestic market, and the least productive firms to exit the market. Thus the exposure to trade leads to inter-firm reallocations towards more productive firms.

\footnotetext{
${ }^{3}$ This is partly due to the data availability constraints faced by the researchers.

${ }^{4}$ In another paper, Feenstra and Weinstein (2010) estimate the magnitude of markup reduction and welfare gain of the US caused by globalization, but the study focuses on the markup reduction of domestic firms in the liberalizing country instead of the markup adjustment of foreign firms exporting to the liberalizing country, and hence it is not directly related to tariff pass-through. In addition, their empirical study is also constrained at the industry level.

${ }^{5}$ Others include Roberts and Tybout (1997), Bernard and Jensen (1999), Bernard, Jensen, Redding, and Schott (2007), etc.
} 
None of the heterogeneous firm models focuses directly on how firm heterogeneity impacts tariff pass-through, though most of them have some implications for this. The first-generation heterogeneous firm models assume constant marginal cost as well as CES utility, with the latter implying constant markups. With constant marginal cost and markups, firms do not have any room for price adjustment. Thus the firm-level tariff pass-through is complete, and the observed incomplete tariff pass-through at the industry level must be completely due to the intra-industry reallocation between firms with different prices. For intra-industry reallocation to explain incomplete tariff pass-through, it must be that, after tariff increase, the surviving exporting firms, which are more productive than the exiting firms, should have lower-than-average prices, so that the average industry price after the tariff increase is lower than before. However, this contradicts the prediction of a large body of heterogeneous firm models that incorporate product quality into CES utility, such as Baldwin and Harrigan (2007), Kugler and Verhoogen (2008), Mandel (2008), and Gervais (2009), among others. These models predict that more productive firms could have higher-than-average prices since they produce high quality differentiated goods. The researchers also provide empirical evidence supporting this prediction. Therefore the firstgeneration heterogeneous firm models based on CES utility and constant markups are not very convincing in explaining the incompleteness of tariff pass-through.

Given this consideration, I switch to the second-generation heterogeneous firm models, beginning with Melitz and Ottaviano (2008). These models feature linear demand and variable markups. With variable markups, the firm-level tariff pass-through could be incomplete, since firms could adjust their markups and hence their exporting prices in response to a tariff change, even if they have constant marginal cost. Antoniades (2008) incorporates product quality into the Melitz and Ottaviano (2008) model. Given the empirical evidence supporting heterogeneous firm models with quality dimension, this model is a good starting point for analyzing firm-level tariff pass-through.

My model is similar to Antoniades (2008). The difference is that the qualityupgrading cost in his model only contains a quantity-invariant $\mathrm{R} \& \mathrm{D}$ cost, but in my model I add another type of quality-upgrading cost, the quantity-dependent component- 
upgrading cost. This extension makes it easier to justify that a firm chooses different quality levels for different markets, which is crucial to guarantee a closed form solution to the model. In my model, exporting firms absorb the tariff change not only by adjusting their markups due to the linear demand structure, but also by adjusting the quality of their products. Both these two adjustments lead to an incomplete tariff pass-through. Moreover, due to the linear demand structure, the absolute magnitude of tariff absorption is identical across firms exporting different varieties of a same product. As a result, for quality differentiated goods with a positive price-productivity schedule, the tariff absorption elasticity is lower for high productivity firms, since they have high initial prices; In contrast, for quality homogeneous goods with a negative price-productivity schedule, the tariff absorption elasticity is higher for high productivity firms, since they have low initial prices. In sum, the model predicts that tariff pass-through depends on both firm heterogeneity in productivity and product differentiation in quality.

In order to empirically verify these predictions, I need to use firm-level data on trade and productivity, as well as product level data on quality scope. From the U.S. Linked/Longitudinal Firm Trade Transaction Database (LFTTD), which links individual U.S. trade transactions to individual U.S. firms, I construct the U.S. firm-level export price changes over time for each exported product to each destination country. From the World Integrated Trade Solution (WITS) I get the tariff rates of other countries against U.S. exports of different products, and calculate the tariff change over time. I also use the U.S. Census of Manufacturing (CMF) data to construct the firm-level productivity, and use the $R \& D /$ sales ratio data from the National Science Foundation or Rauch classification to derive the quality scope of different industries/products. Then I link the tariff data, the firm productivity data, and the product quality scope data to the export price data. Using the combined data, I explore whether the firm-level tariff pass-through is incomplete, as well as how tariff pass-through depends on firm productivity and product quality.

I find evidence supporting the predictions of the model. First, I find that firm-level tariff pass-through is indeed incomplete: The firm-level tariff absorption elasticity is 0.87 on average. Second, I find that all products in the sample on average fit the definition 
of quality differentiated goods, and the tariff absorption elasticity is indeed higher for low productivity firms (1.27) and lower for high productivity firms (0.44), as the model predicts for quality differentiated goods. The overall tariff absorption elasticity and that for low productivity firms are very high, since firms change not only their markups but also their product quality in response to tariff changes. Third, dividing all products into quality homogeneous goods and quality differentiated goods according to various criteria (Rauch classification or $\mathrm{R} \& \mathrm{D} /$ sales ratio) also results in estimates consistent with model predictions for quality differentiated goods.

To my knowledge, this is the first paper that (1) finds empirical evidence for incomplete tariff pass-through at the firm level, and (2) investigates, both theoretically and empirically, how tariff pass-through depends on firm productivity and product quality. Both of these two are contributions of the paper to the tariff pass-through literature. The second one is also a contribution of the paper to the literature on heterogeneous firm models in international trade.

The paper is organized as follows. Section 2 presents the theoretical model. Section 3 contains the empirical strategies. Section 4 describes the data sets. Section 5 includes the estimation results. Conclusions and forward research are in section 6 .

\section{The Model}

\subsection{Consumers and Demand}

As mentioned in section 1, my model is based on Melitz and Ottaviano (2008) and Antoniades (2008). Consider a world consisting of a Home country $(h)$ and a Foreign country $(f)$, with consumers $L^{h}$ and $L^{f}$ in each country. Preferences are defined over a homogeneous good chosen as numeraire, and a continuum of horizontally-differentiated varieties indexed by $i \in \Omega$. Consumers in both countries share the same quasi-linear utility function as in Antoniades (2008):

$$
U=q_{0}^{c}+\alpha \int_{i \in \Omega}\left(q_{i}^{c}+z_{i}\right) d i-\frac{1}{2} \gamma \int_{i \in \Omega}\left(q_{i}^{c}-z_{i}\right)^{2} d i-\frac{1}{2} \eta\left(\int_{i \in \Omega}\left(q_{i}^{c}-\frac{1}{2} z_{i}\right) d i\right)^{2}
$$


where $q_{0}^{c}$ and $q_{i}^{c}$ represent, respectively, the individual consumption levels of the numeraire good and variety $i ; z_{i}$ stands for the quality level of variety $i$, and thus indexes the vertical differentiation of the variety. If the quality level for all varieties is $0\left(z_{i}=0\right.$ for all $i$ ), then the utility function boils down to that in Melitz and Ottaviano (2008). The demand parameters $\alpha$ and $\eta$ index the substitution pattern between the numeraire and the horizontally-differentiated varieties, while the parameter $\gamma$ indexes the degree of horizontal differentiation between the varieties. They are all positive.

The utility function implies the following linear market demand for variety $i$ in country $l \in\{h, f\}$ :

$$
q_{i}^{l} \equiv L^{l} q_{i}^{c}=\frac{\alpha L^{l}}{\eta N^{l}+\gamma}-\frac{L^{l}}{\gamma} p_{i}^{l}+\frac{\eta N^{l} L^{l}}{\left(\eta N^{l}+\gamma\right) \gamma} \bar{p}^{l}+L^{l} z_{i}^{l}-\frac{1}{2} \frac{\eta N^{l} L^{l}}{\eta N^{l}+\gamma} \bar{z}^{l},
$$

where $p_{i}^{l}$ and $z_{i}^{l}$ are, respectively, the price and quality of variety $i$ in country $l ; N^{l}$ is the measure of varieties actually consumed in country $l$ (with $q_{i}^{l}>0$ ); $\overline{p^{l}}=\frac{1}{N} \int_{i \in \Omega^{l}} p_{i}^{l} d i$ and $\bar{z}^{l}=\frac{1}{N} \int_{i \in \Omega^{l}} z_{i}^{l} d i$ are the average price and quality (across both local and foreign firms selling in country $l$ ) of these consumed varieties, where $\Omega^{l} \subset \Omega$ is the subset of varieties that are consumed. The demand function implies: (1) The demand for variety $i$ is negatively related to its own price but positively related to its own quality; (2) It is positively related to the average price of all varieties and negatively related to the average quality of all varieties, and (3) All these relationships are linear.

\subsection{Firms, Production and Export}

Each firm in each country produces a differentiated variety and faces a fixed entry cost $f_{E}$, which is common across firms. Subsequent production of firm $i$ incurs the following total cost function:

$$
T C_{i}=c_{i} q_{i}+b q_{i} z_{i}+\theta\left(z_{i}\right)^{2}
$$

where $q_{i}$ and $z_{i}$ are the quantity and quality of the variety that the firm produces. The first term on the right hand side, $c_{i} q_{i}$, depends on the quantity but not the quality of output, 
and could be interpreted as "processing cost" of a firm. The third term, $\theta\left(z_{i}\right)^{2}$, depends on the quality level of the output but fixed with respect to the quantity of output, which captures the definition of "R\&D cost" for quality upgrading. The second term, $b q_{i} z_{i}$, depends on both the quantity and the quality of the output, which captures the definition of "component-upgrading cost" associated with quality upgrading. A firm could choose a component with one quality level for the home market but another component with another quality level for the foreign market.

There are three points that need to be mentioned. First, both the "processing cost" and the "R\&D cost" exist in Antoniades (2008), but the "component-upgrading cost" is what I add to his model. The purpose for this extension is to justify that a firm can choose different product quality levels for different markets, which is crucial to ensure a closed form solution to the model, as will be shown below. Second, $c_{i}$ is a firm-specific constant which indexes the marginal processing cost; parameters $b$ and $\theta$ are productspecific constants which index the "toughness" of quality upgrading for a product, but they are common across all firms producing different varieties of the same product. Firms learn about their individual $c_{i}$ only after making the irreversible investment $f_{E}$ required for entry, but $b$ and $\theta$ are common knowledge. Third, $c_{i}$ is the marginal "processing" cost of the firm, and the overall marginal cost of the firm is $M C_{i}=c_{i}+b z_{i}$, where $z_{i}$ is a function of $c_{i}$ (as will be shown shortly). $1 / c_{i}$ indexes the processing productivity of the firm, and $1 / M C_{i}$ indexes the overall productivity of the firm.

Consider a firm in the Home country $h$ with parameter $c$. The firm faces both domestic and foreign markets. Assume (1) the two markets are segmented, and (2) the firm chooses separate levels of product quality for the two markets. As mentioned above, the validity of the second assumption is based on the "component-upgrading cost" that I add to Antoniades (2008). These two assumptions, together with the assumption of constant marginal "processing cost" $c$, imply that the firm independently maximizes the 
profits earned from domestic and export sales:

$$
\begin{aligned}
& \pi^{h h}=p^{h h} q^{h h}-c q^{h h}-b q^{h h} z^{h h}-\theta\left(z^{h h}\right)^{2}, \\
& \pi^{h f}=\frac{p^{h f}}{\tau^{f}} q^{h f}-c q^{h f}-b q^{h f} z^{h f}-\theta\left(z^{h f}\right)^{2},
\end{aligned}
$$

where $p^{h h}$ and $p^{h f}$ denote its prices in the domestic and foreign markets; $q^{h h}$ and $q^{h f}$ stand for the corresponding quantities sold in the two markets; $\tau^{f}>1$ is the ad valorem gross tariff rate imposed by the foreign country. Note that the tariff-exclusive export price of the firm is $p^{*}=p^{h f} / \tau^{f}$.

Solutions to the profit maximization problems are:

$$
\begin{aligned}
p^{h h} & =\frac{1}{2}\left(c^{h h}+c\right)+\frac{\gamma+b}{2} z^{h h}, \\
p^{h f} & =\frac{\tau^{f}}{2}\left(c^{h f}+c\right)+\frac{\gamma+b}{2} z^{h f} \\
z^{h h} & =\lambda^{h}\left(c^{h h}-c\right), \\
z^{h f} & =\tau^{f} \lambda^{f}\left(c^{h f}-c\right) .
\end{aligned}
$$

where $c^{h h}=\sup \left\{c: \pi^{h h}>0\right\}$ and $c^{h f}=\sup \left\{c: \pi^{h f}>0\right\}$ are cost upper bounds for firms to earn positive profits from domestic and export sales; $\lambda^{h}=\frac{(\gamma-b) L^{h}}{4 \gamma \theta-(\gamma-b)^{2} L^{h}}$ and $\lambda^{f}=\frac{(\gamma-b) L^{f}}{4 \gamma \theta-(\gamma-b)^{2} L^{f}}$. It is easy to show that $c^{h f}=c^{f f} / \tau^{f}$. Assume that $\gamma-b>0$, $4 \gamma \theta-(\gamma-b)^{2} L^{h}>0$ and $4 \gamma \theta-(\gamma-b)^{2} L^{f}>0$ to ensure $z^{h h}$ and $z^{h f}$ to be positive.

It is easy to show that the level of quality upgrading that the firm chooses $\left(z^{h h}\right.$ or $\left.z^{h f}\right)$ is increasing in the processing productivity of the firm $(1 / c)$, the market size $\left(L^{h}\right.$ or $L^{f}$ ), and the degree of product horizontal differentiation $(\gamma)$, but it is decreasing in the toughness for quality upgrading $(\theta$ and $b)$. The intuition for these conclusions is straightforward and thus is omitted here.

\subsection{Equilibrium and Price Structure}

The free entry condition implies that the expected profits from domestic and export 
sales should be equal to the fixed entry cost, $f_{E}$, that is,

$$
\int_{0}^{c^{h h}} \pi^{h h} d G(c)+\int_{0}^{c^{h f}} \pi^{h f} d G(c)=f_{E}
$$

where $G(c)$ is the distribution of the "processing cost" $c$. Assume that this cost has a Pareto distribution with parameter $k$ and upper bound $c_{M}$ : $G(c)=\left(c / c_{M}\right)^{k}$, where $c \in\left[0, c_{M}\right]$. Substituting this and (4)-(5) into (6), doing the same thing for the free-entry condition in the foreign country, and using $c^{h f}=c^{f f} / \tau^{f}$, I get the two cost bounds:

$$
\begin{aligned}
& c^{h h}=\left[\frac{(\gamma-b) \phi}{\lambda^{h}} \frac{1-\rho^{f}}{1-\rho^{f} \rho^{h}}\right]^{\frac{1}{k+2}}, \\
& c^{h f}=\left[\frac{(\gamma-b) \phi}{\lambda^{f}} \frac{1-\rho^{h}}{1-\rho^{h} \rho^{f}}\right]^{\frac{1}{k+2}} / \tau^{f},
\end{aligned}
$$

where $\phi=\frac{1}{2 \theta}(k+1)(k+2) c_{M}^{k} f_{E}$ and $\rho^{l}=\left(\tau^{l}\right)^{-k}$. Equations (5) and (7) determine the closed form solutions to the model.

It is very helpful to have a careful examination for the internal structure of the equilibrium export price. As mentioned before, the incompleteness of tariff pass-through is equivalent to "tariff absorption" of exporting firms, i.e., an adjustment of their tariffexclusive prices. Since the export price data used in the empirical analysis is tariffexclusive (see section 4), I will focus on the tariff-exclusive price of a firm:

$$
\begin{aligned}
p^{*} & =\frac{p^{h f}}{\tau^{f}} \\
& =\frac{1}{2}\left(c^{h f}+c\right)+\frac{(\gamma+b)}{2} \frac{z^{h f}}{\tau^{f}} \\
& \equiv p_{q}^{*}+p_{z}^{*} \\
& =\frac{1}{2}\left(c^{h f}+c\right)+\frac{(\gamma+b) \lambda^{f}}{2}\left(c^{h f}-c\right) \\
& =\frac{1+(\gamma+b) \lambda^{f}}{2} c^{h f}+\frac{1-(\gamma+b) \lambda^{f}}{2} c \\
& =\frac{2 \gamma \theta+b(\gamma-b) L^{f}}{4 \gamma \theta-(\gamma-b)^{2} L^{f}} c^{h f}+\frac{2 \gamma \theta-\gamma(\gamma-b) L^{f}}{4 \gamma \theta-(\gamma-b)^{2} L^{f}} c .
\end{aligned}
$$

The first equality is the definition of the tariff-exclusive export price. The second equality shows that the price consists of two components: the first term, $\frac{1}{2}\left(c^{h f}+c\right)$, 
is derived from the quantity processing; the second term, $\frac{(\gamma+b)}{2} \frac{z^{h f}}{\tau^{f}}$, is derived from the quality upgrading. I refer to these two terms as the quantity component $p_{q}^{*}$ and the quality component $p_{z}^{*}$, respectively — as indicated by the third equality (equivalence).

The forth equality shows the relationship between these two components and firm processing productivity. The quantity component, $p_{q}^{*}=\frac{1}{2}\left(c^{h f}+c\right)$, is negatively related to firm processing productivity $(1 / c)$, i.e.,

$$
\frac{\partial p_{q}^{*}}{\partial\left(\frac{1}{c}\right)}<0
$$

I refer to this as the "processing effect": the higher is firm processing productivity, the lower is the marginal processing cost, and hence the lower is the unit price. The quality component, $p_{z}^{*}=\frac{(\gamma+b) \lambda^{f}}{2}\left(c^{h f}-c\right)$, is positively related to firm productivity $(1 / c)$, i.e.,

$$
\frac{\partial p_{z}^{*}}{\partial\left(\frac{1}{c}\right)}>0
$$

I refer to this as the "quality effect": the higher is firm processing productivity, the higher is the product quality level that the firm will choose (as mentioned in section 2.2), and thus the higher is the quality-upgrading cost and the unit price.

The fifth and the sixth (the last) equalities describe the relationship between the overall price and firm processing productivity. From these two equalities it is easy to get

$$
\begin{aligned}
& \frac{\partial p^{*}}{\partial\left(\frac{1}{c}\right)}<0 \quad \text { iff } \quad \frac{2 \theta}{L^{f}}+b>\gamma \\
& \frac{\partial p^{*}}{\partial\left(\frac{1}{c}\right)}>0 \quad \text { iff } \quad \frac{2 \theta}{L^{f}}+b<\gamma
\end{aligned}
$$

The intuition is as follows. The condition $\frac{2 \theta}{L^{f}}+b>\gamma$ implies that (1) the qualityupgrading toughness for the product, $\theta$ and $b$, are relatively high, (2) the market size, $L^{f}$, is relatively small, and (3) the product horizontal differentiation $\gamma$ is relatively low. All these three imply that the quality level chosen by all firms (producing different varieties of the same product) is relatively low (as mentioned in section 2.2), and the product has low scope for quality differentiation. As the result, the "processing effect" dominates 
the "quality effect", and hence the overall price is negatively related to firm processing productivity - I refer to this type of products as "quality homogeneous goods".

In contrast, the condition $\frac{2 \theta}{L^{f}}+b<\gamma$ implies that (1) the quality-upgrading toughness for the product, $\theta$ and $b$, are relatively low, (2) the market size, $L^{f}$, is relatively large, and (3) the product horizontal differentiation $\gamma$ is relatively high. All these three imply that the quality level chosen by all firms is relatively high, and the product has high scope for quality differentiation. As the result, the "quality effect" dominates the "processing effect", and hence the overall price is positively related to firm processing productivity I refer to this type of products as "quality differentiated goods".

An interesting observation here is that the horizontal differentiation of a product $\gamma$ is related to the vertical differentiation or quality scope of the product. A product with low horizontal differentiation $\gamma$ is also likely to have low vertical differentiation or quality scope, and thus is likely to be a quality homogeneous good. A product with high horizontal differentiation $\gamma$ is also likely to have high vertical differentiation or quality scope, and thus is likely to be a quality differentiated good.

\subsection{Tariff Absorption, Firm Productivity and Product Quality}

Now I shall turn to explore how a tariff change impacts the tariff-exclusive price $p^{*}$. The third and forth equalities in equation (8) imply that this impact can be decomposed into the impacts of the tariff change on the two components of the price. More specifically, this impact is

$$
\begin{aligned}
\frac{\partial p^{*}}{\partial \tau^{f}} & =\frac{\partial p_{q}^{*}}{\partial \tau^{f}}+\frac{\partial p_{z}^{*}}{\partial \tau^{f}}=\frac{1}{2} \frac{\partial c^{h f}}{\partial \tau^{f}}+\frac{\left[(\gamma+b) \lambda^{f}\right]}{2} \frac{\partial c^{h f}}{\partial \tau^{f}} \\
& =-\frac{2 \gamma \theta+b(\gamma-b) L^{f}}{4 \gamma \theta-(\gamma-b)^{2} L^{f}} \frac{1}{\left(\tau^{f}\right)^{2}}\left[\frac{(\gamma-b) \phi}{\lambda^{f}} T\right]^{\frac{1}{k+2}}\left(\frac{k}{k+2} \Gamma+1\right)<0
\end{aligned}
$$


in terms of the absolute magnitude, and

$$
\begin{aligned}
\Theta^{*} & \equiv \frac{\partial p^{*}}{\partial \tau^{f}} \frac{\tau^{f}}{p^{*}} \\
& =-\frac{\left[\frac{(\gamma-b) \phi}{\lambda^{f}} T\right]^{\frac{1}{k+2}}\left(\frac{k}{k+2} \Gamma+1\right)}{\left[\frac{(\gamma-b) \phi}{\lambda^{f}} T\right]^{\frac{1}{k+2}}+\frac{2 \gamma \theta-\gamma(\gamma-b)^{2} L^{f}}{2 \gamma \theta+b(\gamma-b) L^{f}} \tau^{f} C}<0,
\end{aligned}
$$

in terms of the relative magnitude, where $T=\frac{1-\rho^{h}}{1-\rho^{h} \rho^{f}}$ and $\Gamma=\frac{\rho^{h} \rho^{f}}{1-\rho^{h} \rho^{f}}$. These two inequalities states the incompleteness of tariff pass-through, i.e., "tariff absorption": the tariff-exclusive export price increases in response to a tariff reduction. $\Theta^{*}$ is the tariff absorption elasticity.

There are three things worth pointing out. First, it is easy to see that both the quantity component and the quality component of the tariff-exclusive export price increase in response to a tariff reduction, that is, $\frac{\partial p_{q}^{*}}{\partial \tau^{f}}<0$ and $\frac{\partial p_{z}^{*}}{\partial \tau^{f}}<0$. The increase of the quantity component of the price is essentially an increase in its markup, i.e., $\frac{\partial u_{q}}{\partial \tau^{f}}<0$, where $u_{q}=p_{q}^{*}-c=\frac{1}{2}\left(c^{h f}-c\right)$, since the processing cost $c$ is fixed. This markup adjustment is possible because of the linearity of the demand structure. The increase of the quality component of the price is caused by the quality upgrading of the product in response to the tariff reduction, that is, $\frac{\partial z^{h f}}{\partial \tau^{f}}<0 .{ }^{6}$ In sum, when exporting firms face a tariff reduction, they will not only increase their markups due to the linear demand structure, but also upgrade the quality level of their products. That is, they will transfer the cost advantage due to tariff reduction to higher markups and quality advantage. Thus the model shows that both markup adjustment and quality adjustment are sources of firmlevel tariff absorption.

Second, it is easy to see that the absolute magnitude of tariff absorption does not

\footnotetext{
${ }^{6}$ We can also show the following. (1) The increase of the quality component of the price caused by the quality upgrading is due to the increase of quality-upgrading cost, i.e., $\frac{\partial c_{z}}{\partial \tau^{f}}<0$, where $c_{z}=\left[b q^{h f} z^{h f}+\theta\left(z^{h f}\right)^{2}\right] / q^{h f}$ is the unit quality-upgrading cost. (2) However, the sign of the markup change associated with quality-upgrading, $\frac{\partial u_{z}}{\partial \tau}$, is ambiguous, where $u_{z}=p_{z}^{*}-c_{z}$. (3) Firms with high processing productivity and high initial quality will upgrade their quality less than firms with low processing productivity, i.e., $\partial\left|\frac{\partial z^{h f}}{\partial \tau^{f}}\right| / \partial\left(\frac{1}{c}\right)<0$.
} 
depend on firm processing productivity, i.e.,

$$
\frac{\partial\left(\partial p^{*} / \partial \tau^{f}\right)}{\partial\left(\frac{1}{c}\right)}=0
$$

This is because that the export price, $p^{*}=\frac{1+(\gamma+b) \lambda^{f}}{2} c^{h f}+\frac{1-(\gamma+b) \lambda^{f}}{2} c$, consists of two additively separable components: the first one (containing $c^{h f}$ ) depends on the foreign tariff but not the processing productivity, and the second one depends on the processing productivity but not the foreign tariff. ${ }^{7}$ When the tariff changes, only the first component changes, and hence the change is independent of the processing productivity. ${ }^{8}$

Third, since the initial export price does depend on firm processing productivity (see (11) and (12)), the relative magnitude of tariff absorption, i.e., the tariff absorption elasticity, also depends on firm processing productivity. From (14) I can show that

$$
\begin{aligned}
& \frac{\partial \Theta^{*}}{\partial\left(\frac{1}{c}\right)}<0 \quad \text { iff } \quad \frac{2 \theta}{L^{f}}+b>\gamma \\
& \frac{\partial \Theta^{*}}{\partial\left(\frac{1}{c}\right)}>0 \quad \text { iff } \quad \frac{2 \theta}{L^{f}}+b<\gamma
\end{aligned}
$$

Note that the condition $\frac{2 \theta}{L^{f}}+b>\gamma$ implies that the product is a quality homogeneous good (see (11)). For this type of product, the initial export price is negatively related to firm processing productivity. Thus the relative magnitude of tariff absorption, i.e., the tariff absorption elasticity, in terms of its absolute value, is positively related to firm processing productivity $(1 / c)^{9}$. In contrast, the condition $\frac{2 \theta}{L^{f}}+b<\gamma$ implies that the product is a quality differentiated good (see (12)). For this type of product, the initial export price is positively related to firm processing productivity. Thus the tariff absorption elasticity, in terms of its absolute value, is negatively related to firm processing productivity.

Notice that in (11)-(12) and (15)-(17), I focus on the relationship between export price or tariff absorption and firm "processing" productivity $(1 / c)$. It is easy to show that, for exported goods, the overall marginal cost is $M C=c+b z^{h f}=c+b \lambda\left(c^{h f}-c\right)=$

\footnotetext{
${ }^{7}$ This characteristic is generated by the linearity of the market demand.

${ }^{8}$ Actually this analysis is also true for both the quantity and the quality components of the price.

${ }^{9}$ Notice the difference between the "negative" sign of the partial derivative and the "positive" word interpretation in terms of absolute value. Same for inequality (17) below.
} 
$b \lambda c^{h f}+(1-b \lambda) c$. Under the condition $1-b \lambda>0$ (which I assume is true), the overall marginal cost $M C$ and the marginal "processing" cost $(c)$ are positively correlated. Then the relationships mentioned above could be re-written and re-interpreted in terms of firm overall productivity $(1 / M C)$. In short, the impacts of firm overall productivity and product quality on price level and tariff absorption can be summarized as below:

For both quality homogeneous goods and quality differentiated goods:

$$
\frac{\partial\left(\partial p^{*} / \partial \tau^{f}\right)}{\partial\left(\frac{1}{M C}\right)}=0
$$

For quality homogeneous goods:

$$
\frac{\partial p^{*}}{\partial\left(\frac{1}{M C}\right)}<0, \quad \frac{\partial \Theta^{*}}{\partial\left(\frac{1}{M C}\right)}<0
$$

For quality differentiated goods:

$$
\frac{\partial p^{*}}{\partial\left(\frac{1}{M C}\right)}>0, \quad \frac{\partial \Theta^{*}}{\partial\left(\frac{1}{M C}\right)}>0
$$

From equation (14) it is also easy to derive the following conclusions about the impacts of market size $L^{f}$ and initial tariff $\tau^{f}$ on tariff absorption elasticity:

For quality homogeneous goods:

$$
\frac{\partial \Theta^{*}}{\partial L^{f}}><0, \quad \frac{\partial \Theta^{*}}{\partial \tau^{f}}>0
$$

For quality differentiated goods:

$$
\frac{\partial \Theta^{*}}{\partial L^{f}}<0, \quad \frac{\partial \Theta^{*}}{\partial \tau^{f}}><0
$$

In words, for quality homogeneous goods, there is an ambiguous relationship between tariff absorption elasticity and the foreign market size, and a negative relationship between tariff absorption elasticity (in terms of its absolute value) and the initial foreign tariff rate. On the other hand, for quality differentiated goods, there is a positive relationship 
between tariff absorption elasticity (in terms of its absolute value) and the foreign market size, as well as an ambiguous relationship between tariff absorption elasticity and the initial foreign tariff rate.

\section{Empirical Strategies}

Now I turn to the empirical side to test the predictions of the model on tariff passthrough. As mentioned before, since the export prices I will get from the trade data are tariff-exclusive, I will focus on exploring how tariff changes impact the tariff-exclusive prices, i.e., tariff absorption, and how this impact depends on firm productivity, product quality and other factors.

The main predictions of the model are: (i) The firm-level tariff pass-through is incomplete, that is, firms do absorb tariff change (see (13) and (14)). (ii) The absolute tariff absorption does not depend on firm productivity, for either quality homogeneous goods or quality differentiated goods (see (15)). (iii) The relationship between the relative tariff absorption (tariff absorption elasticity) and firm productivity depends on whether the good is a quality homogeneous good or quality differentiated good (see (16) and (17)). The model also has some predictions on how market size and the initial tariff rate of the destination country impact tariff absorption elasticity (see (18) and (19)). I test these predictions in two different ways: by pooling all products in the sample, and by dividing them into "quality homogeneous goods" and "quality heterogeneous goods".

\subsection{All Products Pooled}

In this subsection, I pool all products in the sample, and test model predictions step by step. First, I use the following specification to check whether the products, on average, are quality homogeneous goods or quality differentiated goods:

$$
\begin{aligned}
\ln P_{i f c t}^{*}= & \beta \ln T F P_{f t}+\delta_{i c t}+\mu_{i f c t} . \\
& (-: \text { homogeneous }) \\
& (+: \text { differentiated })
\end{aligned}
$$


where $\ln P_{i f c t}^{*}$ denotes the $\log$ tariff-exclusive price of product $i$ exported by firm $f$ to country $c$ in period $t, \ln T F P_{f t}$ represents the $\log$ total factor productivity ${ }^{10}$ of firm $f$ in period $t, \delta_{i c t}$ stands for a product-country-period fixed effect, and $u_{i f c t}$ is the error term. Coefficient $\beta$ measures how export prices are related to firm productivity: if $\beta$ is negative, then the products, on average, are quality homogeneous goods (see (11)); if $\beta$ is positive, then the products, on average, are quality differentiated goods (see (12)).

Second, I use the following specification to check whether the absolute tariff absorption depends on firm productivity or not:

$$
\Delta P_{i f c t}^{*}=\beta_{1} \Delta \tau_{i c t}+\beta_{2} \operatorname{lnTFP} P_{f(t-1)}+\beta_{12}\left[\Delta \tau_{i c t} \times \operatorname{lnTFP} P_{f(t-1)}\right]+F E+\mu_{i f c t},
$$

$$
(-)
$$

where $\Delta P_{i f c t}^{*}$ denotes the absolute change of the tariff-exclusive price of product $i$ exported by firm $f$ to country $c$ from period $t-1$ to period $t, \Delta \tau_{i c t}$ is tariff change of country $c$ on product $i$ from period $t-1$ to period $t, T F P_{f(t-1)}$ is the TFP of firm $f$ in the base year $t-1$, and $F E$ stands for various fixed effects ${ }^{11}$. Coefficient $\beta_{1}$ measures the absolute change of the tariff-exclusive price of a benchmark firm (with $\operatorname{lnTFP} P_{f(t-1)}=0$ ) in response to the tariff change. This coefficient should be negative according to (13); however, since the absolute magnitudes of export price changes for different products are not comparable, the magnitude of $\beta_{1}$ is meaningless. The coefficient of the interaction term between tariff change and firm TFP, $\beta_{12}$, measures how firm productivity impacts the absolute change of the export price in response to the tariff change. This coefficient should be 0 (that is, insignificant) according to (15). The separate TFP term is added in this specification in case firm productivity (or cost) has a direct effect on price change, but the model does not have a prediction about the sign of this direct effect.

\footnotetext{
${ }^{10}$ This total factor productivity corresponds to the "overall" firm productivity $1 / M C$ instead of the "processing" productivity $1 / c$ in section 2.

${ }^{11}$ Note that since the specification that I use is first order difference, I have already removed all timeinvariant fixed effects (including product, firm, country, product-firm, product-country, firm-country, and product-firm-country fixed effect) on price levels. The fixed effects here and those in the regressions hereafter refer to fixed effects on price changes.
} 
Third, I use the following regression to estimate the tariff absorption elasticity:

$$
\Delta \ln P_{i f c t}^{*}=\beta \Delta \ln \left(1+\tau_{i c t}\right)+F E+\mu_{i f c t}
$$

$$
(-)
$$

Notice that I now have logs for both the price change and the tariff change. Thus coefficient $\beta$ measures the percent change of tariff-exclusive prices in response to percent change of tariff rates, that is, it measures tariff absorption elasticity. It should be negative according to (14). Also notice that I have gross tariff rate $\left(1+\tau_{i c t}\right)$ on the right hand side since that is the tariff rate in the theoretical model ${ }^{12}$.

Next, I add firm productivity and its interaction with the relative tariff change to estimate its direct effect on price change and its impact on tariff absorption:

$$
\begin{aligned}
\Delta l n P_{i f c t}^{*}= & \beta_{1} \Delta \ln \left(1+\tau_{i c t}\right)+\beta_{2} T F P H_{f(t-1)}+\beta_{12}\left[\Delta \ln \left(1+\tau_{i c t}\right) \times T F P H_{f(t-1)}\right] \\
(-) \quad(-: \text { homogeneous }) & (+: \text { differentiated }) \\
& +\beta_{3} \Delta \ln G D P_{c t}+\beta_{4} \Delta \ln X R_{c(t-1)}+F E+\mu_{i f c t}, \\
& (+) \quad
\end{aligned}
$$

This specification is a counterpart of (21), but with two differences: (1) Here I have logs for both the price change and the tariff change; (2) Here I use a high TFP dummy TFPH $H_{f(t-1)}$ to replace the level of firm TFP - This dummy is set to 1 if the TFP of the exporting firm $f$ in the base year $t-1, T F P_{f(t-1)}$, is higher than the average TFP of all firms exporting the same product $i$ to the same destination country $c$, and 0 otherwise. Now the coefficient for the tariff change, $\beta_{1}$, measures the tariff absorption elasticity for low productivity firms. According to the model, it should be negative (by (14)). The coefficient for the interaction term between tariff change and the high TFP dummy, $\beta_{12}$, measures the difference between the tariff absorption elasticity for high productivity firms and the elasticity for low productivity firms. A negative $\beta_{12}$ implies that high productivity

\footnotetext{
${ }^{12}$ In specification (21) I have the absolute change of net tariff rate since that is equivalent to absolute change of gross tariff rate, i.e., $\Delta \tau_{i c t}=\Delta\left(1+\tau_{i c t}\right)$.
} 
firms have a higher tariff absorption elasticity (in absolute value) than low productivity firms, since the elasticity itself is negative, while a positive $\beta_{12}$ implies that the opposite is true. According to the model, $\beta_{12}$ should be negative for quality homogeneous goods (by (16)), but positive for quality differentiated goods (by (17)).

I also add two other control variables in the regression. The first one is change of log real GDP of the destination country, $\Delta \ln G D P_{c t}$, which is used to control for the change of market demand. An increase of the market demand should push up export prices, and thus $\beta_{3}$ should be positive. The second one is change of log exchange rate (measured as units of foreign currency per U.S. dollar) one period before tariff change, $\Delta \ln X R_{c(t-1)}^{13}$. A dollar appreciation should cause U.S. exporting firms to lower their export prices denominated in U.S. dollars ${ }^{14}$, and thus $\beta_{4}$ should be negative.

Finally, I add the market size and the initial tariff of the destination country, as well as their interaction with the relative tariff change, to estimate their impacts on price change and tariff absorption:

$$
\begin{gathered}
\Delta \ln P_{i f c t}^{*}=\beta_{1} \Delta \ln \left(1+\tau_{i c t}\right)+\beta_{2} \text { TFP }_{f(t-1)}+\beta_{12}\left[\Delta \ln \left(1+\tau_{i c t}\right) \times T F P H_{f(t-1)}\right] \\
(-) \quad(+: \text { homogeneous }) \\
+\beta_{3} \ln G D P_{c(t-1)}+\beta_{13}\left[\Delta \ln \left(1+\tau_{i c t}\right) \times \ln G D P_{c(t-1)}\right] \\
(+/-: \text { homogeneous }) \\
(-: \text { differentiated }) \\
+\beta_{4} \ln \left(1+\tau_{i c(t-1)}\right)+\beta_{14}\left[\Delta \ln \left(1+\tau_{i c t}\right) \times \ln \left(1+\tau_{i c(t-1)}\right)\right] \\
(+: \text { homogeneous }) \\
+\beta_{5} \Delta \ln G D P_{c t}+\beta_{6} \Delta \ln X R_{c(t-1)}+F E+\mu_{i f c t}, \\
(+) \quad(+)
\end{gathered}
$$

\footnotetext{
${ }^{13}$ I use the lagged exchange rate changes because exchange rate changes typically have a lag effect, as shown in the exchange rate pass-through literature.

${ }^{14}$ As shown in the exchange rate pass-through literature.
} 
where $\ln G D P_{c(t-1)}$ is $\log$ of GDP of country $c$ in the base year, which measures its market size in the base year, and $\tau_{i c(t-1)}$ is the initial tariff rate in the base year. Again here coefficient $\beta_{1}$ should be negative according to the model. The coefficients for the three interaction terms, $\beta_{12}, \beta_{13}$, and $\beta_{14}$, measure the impact of firm productivity, market size, and initial tariff rate on tariff absorption elasticity. Their signs are determined by (16)(19). Coefficients $\beta_{2}, \beta_{3}$ and $\beta_{4}$ are direct effects of firm productivity, market size and initial tariff rate on price change, but the model does not have a prediction on their signs.

\subsection{Quality Homogeneous Goods vs. Quality Differentiated Goods}

Now I divide all products into two groups, "quality homogeneous goods" and "quality differentiated goods", and run the regressions specified above separately for the two groups.

Since product quality is not directly observed, it is hard to find a very good criterion to identify the quality scope of a product. A potential criterion is the price-productivity schedule for each individual product. According to the model, if a product has a negative price-productivity schedule, then it could be classified as a quality homogeneous good; if it has a positive price-productivity schedule, then it could be classified as a quality differentiated good. However, this method may have an endogeneity problem: if I use the price-productivity schedule to classify the products in the first stage, and then explore the relationship between price changes (in response to tariff changes) and firm productivity for each group of products in the second stage, the dependent variable and the independent variables in the first stage are related to those in the second stage, and thus there may exist an endogeneity problem between these two stages.

Given this consideration, I turn to exogenous criteria for product quality scope. The first one that I am going to use is the Rauch classification. Rauch (1999) classifies products into commodities and differentiated goods: goods traded on organized exchanges or with reference prices are classified as commodities, and others are classified as differentiated goods. Intuitively speaking, products traded on organized exchanges or with reference prices should have relatively low scope for quality differentiation, and other products 
should have relatively high scope for quality differentiation. Thus I treat commodities in Rauch classification as quality homogeneous goods, and differentiated goods in Rauch classification as quality differentiated goods.

The second criterion that I use to identify the product quality scope is the R\&D investment for different industries/products. The model implies that quality upgrading is associated with both $\mathrm{R} \& \mathrm{D}$ cost and component-upgrading cost. The higher are those costs in an industry, the higher should be the scope for quality differentiation. As will be seen in section $4, \mathrm{R} \& \mathrm{D}$ investment data are available for a wide range of industries, while the data for component upgrading cost are not. Thus I use the R\&D investment for different industries to classify products: If a product is in an industry with a low $\mathrm{R} \& \mathrm{D} /$ sales ratio, then it is classified as a quality homogeneous good; otherwise, it is classified as a quality differentiated good.

People may question that the Rauch classification may reflect horizontal differentiation instead of quality (vertical) differentiation, and the R\&D investment may also be used to make horizontal differentiation instead of quality (vertical) differentiation for a product. This is a reasonable concern. However, as shown in the section 2.3, the level of quality (vertical) differentiation of a product is roughly positively related to the level of horizontal differentiation of the product: products with low level of horizontal differentiation (low $\gamma$ ) are more likely to be quality homogeneous goods, and products with high level of horizontal differentiation are more likely to be quality differentiated goods. Thus even though using the Rauch classification or the R\&D investment to identify product quality scope may not be accurate, they are not too bad approximation, especially when there are no other better alternatives. As will be seen in section 5, using these two criteria to classify products does result in estimates consistent with model predictions for quality differentiated goods.

\section{Data}

We need four types of data for empirical analysis: trade data, tariff data, firm productivity data, and product quality scope data. 
The trade data are used to compute firm-level export prices. The data that I use is the U.S. Linked/Longitudinal Firm Trade Transaction Database (LFTTD), which was assembled by Bernard, Jensen and Schott (2008). The data link all individual U.S. import and export transactions to the respective U.S. importing and exporting firms. The dataset comes from two sources: the first one is the foreign trade data (FTD) assembled by the U.S. Census Bureau and U.S. customs, which contains all U.S. international trade transactions between 1992 and 2005 inclusive; the second is the Longitudinal Business Database (LBD) of the U.S. Census Bureau, which records annual employment and survival information for most U.S. establishments. I use the export data in the LFTTD database. For each export transaction, the database records its product category (at HS10 level), quantity, (tariff-exclusive) value, exporting firm, destination country, year and month in which the transaction occurs, etc.

Before constructing export prices I clean the data in the following way. (1) Among all transactions, I first drop those with missing values in value, quantity, product category, export firm, destination country, or time. (2) Since measurement error in values or quantities causes measurement error for the constructed prices and leads to biased estimation, I remove the transactions (around 5 percent of the total) with extraordinary computed prices which are 20 times larger or smaller than the average price of all transactions in the same product-firm-country-year cell. (3) I also remove related party transactions ${ }^{15}$ (around 30 percent of the total), since the price behavior for related party transactions is quite different from normal arm's length transactions. For the rest of transactions, I construct firm-level prices (unit values) as $P_{i f c t}^{*}=V_{i f c t} / Q_{i f c t}=\sum_{t r} V_{i f c t, t r} / \sum_{t r} Q_{i f c t, t r}$, where $V_{i f c t}$ and $Q_{i f c t}$ are the total value and quantity of product $i$ (HS10) exported by firm $f$ to country $c$ in year $t$, and $V_{i f c t, t r}$ and $Q_{i f c t, t r}$ are the transaction-level value and quantity for the same product exported by the same firm to the same destination country in the same period. Thus the firm-level price $P_{i f c t}^{*}$ is the average transaction-level price weighted by transaction quantity. Since export values are tariff-exclusive, the constructed export prices are also tariff-exclusive. Among all product-firm-country-year cells for which

\footnotetext{
${ }^{15}$ Related-party transactions refer to trade between U.S. companies and their foreign subsidiaries and trade between U.S. subsidiaries of foreign companies and their affiliates abroad.
} 
I constructed export prices, I keep those surviving in two consecutive years. For these surviving cells I get changes of absolute prices $\Delta P_{i f c t}^{*}=P_{i f c t}^{*}-P_{i f c(t-1)}^{*}$ and changes of $\log$ prices $\Delta \ln P_{i f c t}^{*}=\ln P_{i f c t}^{*}-\ln P_{i f c(t-1)}^{*}$.

The tariff data contains the tariff rates of other countries against U.S. exports of different products. The data was collected by the World Integrated Trade Solution (WITS) at the World Bank for the period 1982-2005 ${ }^{16}$. They are annual data at the HS6 level, and thus are more aggregate than the trade data in both time and product dimensions. Since tariff rates are annual, the time dimension $t$ of all variables in all regressions is also year. The actual tariff rate may vary across HS8 or HS10 products within a same HS6 category. For each HS6 category, the data includes the maximum, minimum, and mean tariff rates of all HS8 or HS10 products within the category. I only include HS6 categories within which there is no tariff variation (that is, the maximum, minimum and mean tariff rates are all identical), since it is only for these HS6 categories that I can calculate accurate tariff change over time for products at HS10 level ${ }^{17}, \Delta \tau_{i c t}$. These tariff changes are then merged to U.S. export price changes of corresponding products to corresponding destination countries.

Firm productivity is constructed from the U.S. Census of Manufactures (CMF) collected and maintained by the U.S. Census Bureau. For years ending with 2 or 7 (1987, 1992, 1997, etc.), the data set records the production information (output, capital stocks, labor hours, energy and materials inputs, etc.) for all U.S. manufacturing establishments (plants). From this data I construct plant-level TFP from the typical constant returns to scale index form:

$$
\ln T F P_{p t}=\ln Q_{p t}-\phi_{K} \ln K_{p t}-\phi_{L} \ln L_{p t}-\phi_{E} \ln E_{p t}-\phi_{M} \ln M_{p t}
$$

where $T F P_{p t}$ is the TFP of plant $p$ in period $t ; Q, K, L, E$ and $M$ represent plantlevel output (value of shipment), capital stocks, labor hours, and energy and materials

\footnotetext{
${ }^{16}$ The data is more complete (containing more countries and more products) in more recent years.

${ }^{17}$ For a HS6 industry within which there is tariff variation across HS8 or HS10 products, I can only calculate the change of average tariff rate for the HS6 industry, but not the accurate tariff change for each HS8 or HS10 product.
} 
inputs; and the $\phi$ 's are the factor elasticities for the corresponding inputs. The firm-level productivity, $T F P_{f t}$, is computed as the average of the productivity of the plants within the same firm weighted by their output shares ${ }^{18}$, and is then merged to the U.S. export price changes of corresponding firms.

As discussed in section 3, product quality scope is identified by using the Rauch classification or the R\&D investment data. The R\&D investment data comes from the U.S National Science Foundation (NSF). The data contains U.S R\&D investment at the 2-digit or 3-digit SIC (Standard Industry Classification) industry level for the period 1995-1997. The R\&D investment comes from three different sources: federal funds, company funds and other funds. The data on federal funds in many industries are not publicly available for confidential consideration, but the data on company and other funds are available for almost all industries. The data contains the company and other R\&D investment for each industry as a percent of the net sales of the same industry, the $\mathrm{R} \& \mathrm{D} /$ sales ratio. I merge the data to the trade and tariff data by using a concordance between SIC classification and HS classification, which was created by Pierce and Schott (2009).

I also use GDP data to measure the market size, and use GDP change and exchange rate change as control variables. Both the GDP data and exchange rate data come from Penn World Table.

The benchmark sample that I use for the empirical analysis contains the abovementioned data for the period 1997-1998. The choice of this period is based on the joint consideration of the following facts: (1) The firm productivity data is only available for 1992, 1997 and 2002, (2) the R\&D data is only available for 1995-1997, and (3) there are a wide range of large tariff changes occurred around 1997 in the tariff data. In the benchmark 1997-1998 sample, export price changes and tariff changes are from 1997 to 1998, and firm productivity is for the base year 1997. For R\&D data, since the R\&D investment may have a lag effect, I average the $\mathrm{R} \& \mathrm{D} /$ Sales ratios for each industry for 1995, 1996 and 1997, and use this average ratio as the indicator for R\&D cost of the industry in 1997, the base year in the benchmark sample.

\footnotetext{
${ }^{18} \mathrm{As}$ mentioned in section 3 , total factor productivity corresponds to the "overall" firm productivity $1 / M C$ instead of the "processing" productivity $1 / c$ in section 2.
} 
With all data at hand, I run the regressions in section 3 with two samples. The first sample is the full benchmark sample for 1997-1998. In the second sample, I only include countries with large tariff changes for certain products during the period 1997-1998. More specifically, I only include countries for which there is at least one HS6 industry with tariff change higher than 5 percentage points; but for each of these countries, I keep all industries no matter whether they have large tariff change or not. The purpose of choosing this sample is to ensure that there are enough observations with large tariff changes to induce price changes and, at the same time, there are also enough observations with small tariff changes for the purpose of comparison.

People may wonder whether the construction of the sub-sample containing only countries with large tariff changes will lead to selection bias. To address this concern, I compare some summary statics for the full benchmark sample and the sub-sample. Table 1 lists these summary statistics for the two samples, including number of industries (HS2 and HS6), products (HS10), exporting firms, and destination countries, as well as the total export value in the base year $\left(T V_{t-1}\right)$ and summary statistics for the main variables used in the regressions. The comparison between these two samples shows that even though the sub-sample only contains two thirds of the countries (38 vs. 61) in the full sample, all the other indicators in the two samples are pretty close to each other, which indicates that the sub-sample is quite representative for the full sample. This is because that the countries contained in the sub-sample, which are listed in table 2, not only include all the big trade partners of the U.S. (such as Canada, Mexico, European Union countries, Japan, China, etc.), but also include middle-size countries (such as Egypt, Turkey, Argentina, etc.) and small countries (such as Dominica, Salvador, Honduras, Ecuador, etc.).

Another observation from table 1 is the structure of tariff change. The table shows that, in both the full sample and the sub-sample, observations with tariff reduction account for 43 to 53 percent of all observations, those without any tariff change account for 41 to 53 percent, and those with tariff increase only account for 4 to 6 percent. Thus most of the tariff changes are tariff reductions, and the regression results about tariff absorption in next section could be interpreted as the increases of the tariff-exclusive prices 
in response to tariff reductions.

\section{Empirical Results}

\subsection{All Products Pooled}

In this subsection, I present the regression results for all products together, without dividing them into quality homogeneous goods and quality differentiated goods. I run the regressions specified in section 3 for two samples: the first one is the full benchmark sample for 1997-1998, and the second one is the sub-sample which only contains the 38 countries with large tariff change.

Table 3 contains the results for the full benchmark sample. In column 1 I regress $\log$ of firm-level export prices in the base year on log of firm-level productivity in the base year. This corresponds to specification (20) in section 3, which is used to check the price-productivity schedule and the nature of products in terms of quality scope. Here I use a product-country fixed effect to control any product-country specific determinants for export prices, so that the only variation in export prices unexplained by this fixed effect is the firm level variation. I find a positive and significant relationship between export prices and firm productivity: a 10 percent increase of firm TFP leads to a 0.6 percent increase of the export price. According to the model, this positive price-productivity schedule indicates that all products on average fit the definition of quality differentiated goods.

Column 2 corresponds to specification (21) in section 3, which is used to check whether firm productivity impacts the absolute magnitude of tariff absorption. Here I regress the absolute change of export prices on the absolute change of tariff rates, the firmlevel productivity, as well as their interaction. I use a product and a country fixed effect to control for any product-specific shocks and country-specific shocks (such as exchange rate changes and demand changes) on export price changes. The reason for using these two fixed effects instead of using a product-country fixed effect is that the latter will absorb the effect of tariff change, which is product-country specific. The coefficient for the interaction term between tariff change and firm TFP is not significant. This indicates that firm productivity does not have a significant impact on the absolute magnitude of 
tariff absorption, which is consistent with the model prediction.

In column 3 I regress the relative (log) change of export prices on the relative (log) change of tariff rates. This corresponds to specifications (22) in section 3, which is used to estimate the overall tariff absorption elasticity. Again here I use a product and a country fixed effect. The estimated overall tariff absorption elasticity is -0.87 and is significant. This indicates that the firm-level tariff absorption does exist: on average exporting firms absorb 87 percent of the tariff reduction by increasing their tariff-exclusive prices. In other words, the firm-level tariff pass-through is indeed incomplete: only 13 percent of the tariff reduction is passed on to consumers as lower consumer prices.

You may wonder why the tariff absorption elasticity is so high comparing to the estimates in previous studies at the industry level ${ }^{19}$. There are two possible reasons for this. First, the tariff absorption I get here is at the firm-level and is for incumbent firms after tariff reductions. As shown in the model, these firms not only increase their markups but also upgrade their product quality in response to tariff reductions, and hence their price increase is high. Second, according to the model, the new entrants caused by tariff reductions (which are less productive than incumbents) may have lower-than-average prices since they produce lower quality goods, and thus the average industry-level prices after tariff reductions will only increase by a smaller magnitude, which is consistent with the previous smaller estimates at the industry level.

In column $4 \mathrm{I}$ add the high TFP dummy, which indicates whether the firm TFP is higher than the average, and its interaction with the relative (log) tariff change. This corresponds to specifications (23) in section 3, which is used to estimate the impact of firm productivity on tariff absorption elasticity. Now the coefficient for the relative tariff change term, which measures the tariff absorption elasticity for low productivity firm is -1.27 and significant. A tariff absorption elasticity higher than 1 (in absolute value) implies that, when low productivity firms face a tariff reduction, they increase their tariffexclusive prices so much that the tariff-inclusive consumer prices actually increase instead

\footnotetext{
${ }^{19}$ Recall that in Feenstra (1989), the tariff absorption in the automobile industry is only 40 percent. In Kreinin (1961), the average tariff absorption in all industries is higher at around 67 percent, but still much lower than the estimate in this paper.
} 
of decreasing. This is known as the "Metzler Paradox". The possible reason again lies in quality upgrading: the initial product quality for low productivity firms is low; when they face a tariff reduction, they upgrade their product quality by a significant magnitude, which leads to a high increase in their tariff-exclusive prices. Thus, quality upgrading provides a reasonable explanation for the "Metzler Paradox".

Meanwhile, the coefficient for the interaction term between the relative tariff change and the high TFP dummy is positive and significant (0.83), indicating that high productivity firms actually have lower (in absolute value) tariff absorption elasticity, which is $-0.44(-1.27+0.83=-0.44)$. This is consistent with the model prediction for quality differentiated goods.

In column 5 I add other two control variables: changes of exchange rates and GDPs (which measures the market demand) of the destination countries. Since these two variables are country specific, I drop the country fixed effect and only keep the product fixed effect in the regression. The estimates for these two controls are not significant, but including them in the regression changes the tariff absorption elasticities to -0.89 for low productivity firms and $-0.05(-0.89+0.84=-0.05)$ for high productivity firms. The lower (in absolute value) elasticity for higher productivity firms is still consistent with the model prediction for quality differentiated goods.

Column 6 contains the results for specification (24) in section 3, which is used to check the impacts of market size and initial tariff rate on tariff absorption elasticities. Here I add the GDP (measuring market size) and the initial tariff rate of the destination country in the base year (1997), as well as their interaction with tariff change. The coefficients for these four variables show their direct impacts on price changes and their impacts on tariff absorption. The estimates show that none of these impacts is significant. Notice that in this specification the coefficient for the tariff change term (-4.96) measures the tariff absorption elasticity for low productivity firms $(T F P H=0)$ exporting to a country with a hypothetical GDP $(\ln G D P=0)$ and a hypothetical tariff rate for the product $(\ln (1+$ $\tau)=0$ ), and thus its magnitude is meaningless. However, the positive coefficient for the interaction term between the relative tariff change and the high TFP dummy (0.83) still 
shows that firms with high productivity have lower (in absolute value) tariff absorption elasticity, which is consistent with the model prediction for quality differentiated goods.

Table 4 contains the results for the regressions same as those in table 3, but for the smaller sample that only contains the 38 countries with large tariff change: each country has at least one HS6 industry with tariff change higher than 5 percentage points. This table shows the qualitatively same results as those in table 3. First, there is a positive and significant price-productivity schedule (with estimate 0.05 ), which shows that all products on average fit the definition of quality differentiated goods. Second, the firm-level tariff pass-through is indeed incomplete, and the overall tariff absorption elasticity is -0.65 , as shown in column 3. Third, the absolute magnitude of tariff absorption is independent of firm productivity, as shown by the insignificance of the estimate for the interaction term between the absolute tariff change and firm TFP in column 2. Next, tariff absorption elasticity is higher for low productivity firms, and lower for high productivity firms, as shown by the positive and significant estimates (0.90) for the interaction term between the relative tariff change and the high TFP dummy in columns 4-6. This is consistent with the model predictions for quality differentiated goods. Finally, the impacts of market size and initial tariff rate on tariff absorption are insignificant, as shown by the estimates for the interaction terms between tariff change and GDP as well as initial tariff rate.

In short, the results presented in this subsection show that (1) firm-level tariff absorption does exist, i.e., firm-level tariff pass-through is indeed incomplete; (2) all products on average fit the definition of quality differentiated goods, as they have a positive priceproductivity schedule; and (3) tariff absorption elasticity is higher for low productivity firms and lower for high productivity firms, which is consistent with the model prediction for quality differentiated goods.

\subsection{Quality Homogeneous Goods vs. Quality Differentiated Goods}

In this subsection I divide all products into two categories, "quality homogeneous goods" and "quality differentiated goods", according to various criteria, and then run the same regressions as in section 5.1 separately for these two groups of products. 
As mentioned in section 3, the first criterion that I use to classify products is the Rauch classification: I treat commodities in terms of the Rauch classification as quality homogeneous goods, and treat differentiated goods in terms of Rauch classification as quality differentiated goods. Among the 84,902 observations (product-firm-country-year cells) in the full benchmark sample, only 6,171 belong to quality homogeneous goods, and the other 65,277 belong to quality differentiated goods. Table 5 and table 6 present the regression results for these two groups, respectively.

In table 5 (for commodities), the slope for the price-productivity schedule is not significant and even not negative, as shown in column 1 . This indicates that it may not be accurate to treat all commodities in terms of the Rauch classification as quality homogeneous goods. Once again, the absolute magnitude of tariff absorption is independent of firm productivity, as shown in column 2. Column 3 shows that the overall tariff absorption elasticity is indeed negative and significant (-1.21), indicating that firm-level tariff passthrough is indeed incomplete ${ }^{20}$. The estimates in columns 4-6 for the interaction term between the relative tariff change and the high TFP dummy are all negative (though insignificant), which shows that high productivity firms have a higher (but not significant) tariff absorption elasticity (in absolute value) than low productivity firms. This is qualitatively consistent with the model prediction for quality homogeneous goods. The impacts of market size and initial tariff rate on tariff absorption are again insignificant.

In table 6 (for differentiated products), I do find a positive and significant priceproductivity schedule, as shown in column 1, which shows that differentiated products in terms of the Rauch classification fit the definition of quality differentiated goods. Again column 2 shows that the absolute magnitude of tariff absorption is independent of firm productivity, which is consistent with model predictions. Column 3 shows that the overall tariff absorption elasticity for this group is indeed negative and significant (-0.80), which implies that firm level tariff pass-through is indeed incomplete. Column 4 shows that the tariff absorption elasticity is higher (in absolute value) for low productivity firms (-1.30),

\footnotetext{
${ }^{20} \mathrm{~A}$ surprising finding here is that the tariff absorption elasticity is higher than $1 \mathrm{in}$ absolute value, that is, "Metzler Paradox" also exists for commodities, for which there should be no large quality adjustment in response to tariff change.
} 
and lower (in absolute value) for high productivity firms $(-1.30+1.04=-0.26)$, which is consistent with the model prediction for quality differentiated goods. The positive estimates for the interaction term between tariff change and the high TFP dummy in columns 5-6 show the same conclusion. Again the impacts of market size and initial tariff rate on tariff absorption are insignificant.

As also indicated in section 3 , the second criterion that I use to classify products is the $\mathrm{R} \& \mathrm{D} /$ sales ratio for different industries/products. I treat goods with $\mathrm{R} \& \mathrm{D} /$ sales ratios lower than the 25 th percentile of $\mathrm{R} \& \mathrm{D} /$ sales ratios for all products in the full benchmark sample as quality homogeneous goods, and other goods as quality differentiated goods. The reason for using the 25th percentile as the cutoff is that, comparing to the mean or median, this cutoff leads to 15,408 observations in the group of quality homogeneous goods and 69,494 observations in the group of quality differentiated goods, which are close to sample sizes of the two groups under the Rauch classification ${ }^{21}$. Table 7 and table 8 present the regression results for these two groups of products, respectively.

In table 7 (for products with low R\&D/sales ratios), I did not find a negative and significant price-productivity schedule, as shown in column 1, which indicates that it may not be accurate to treat all products with low $\mathrm{R} \& \mathrm{D} /$ sales ratios as quality homogenous goods. Again the absolute magnitude of tariff absorption is independent of firm productivity, as shown by the insignificance of the estimate for the interaction term between tariff change and TFP in column 2. Column 3 shows that the overall tariff absorption elasticity is not significant for this group of goods. The estimates in columns 4-6 for the interaction term between the relative tariff change and the high TFP dummy are all insignificant, which shows that the impact of firm productivity on tariff absorption is insignificant for this group of goods. The last column shows that the impacts of market size and initial tariff rate on tariff absorption are also insignificant.

In table 8 (for products with high $\mathrm{R} \& \mathrm{D} /$ sales ratios), I do have a positive and significant price-productivity schedule, as shown in column 1, which shows that products with high $\mathrm{R} \& \mathrm{D} /$ sales ratios do fit the definition of quality differentiated goods. Again

\footnotetext{
${ }^{21}$ The correlation between these two classifications is 0.30 , indicating that vertical (quality) differentiation and horizontal differentiation are indeed positively correlated.
} 
column 2 shows that the absolute magnitude of tariff absorption is independent of firm productivity, which is consistent with model predictions. Column 3 shows that the overall tariff absorption elasticity is -1.01 and significant for this group, which again confirms the incompleteness of firm-level tariff pass-through and the "Metzler Paradox". Column 4 shows that the tariff absorption elasticity is higher (in absolute value) for low productivity firms $(-1.60)$, and lower (in absolute value) for high productivity firms $(-1.60+1.23=$ -0.37 , which is consistent with the model prediction for quality differentiated goods. The positive estimates for the interaction term between the relative tariff change and the high TFP dummy in columns 5-6 show the same conclusion. Again the last column shows that the impacts of market size and initial tariff rate on tariff absorption are insignificant.

In short, the regression results presented in this subsection show that dividing all products into "quality homogeneous goods" and "quality differentiated goods" in terms of various criteria (either the Rauch classification or the $\mathrm{R} \& \mathrm{D} /$ Sales ratios) results in estimates consistent with the model predictions for the group of quality differentiated goods, but not for the group of quality homogeneous goods - Actually the group of quality homogeneous goods that I got in terms of the two criteria does not fully fit the definition of quality homogeneous goods, since they do not have a significant negative price-productivity schedule. Thus, I attribute this inconsistency between theory and empirics to the empirical measurement error instead of the failure of the model.

\section{Conclusions}

This paper explores the incompleteness of tariff pass-through at the firm level, as well as its dependence on firm heterogeneity in productivity and product differentiation in quality. On the theoretical side, I use an extended version of the Melitz and Ottaviano (2008) model and show that, when exporting firms face a foreign tariff change, they will absorb part of the tariff change by adjusting both their markups and their product quality, which leads to an incomplete tariff pass-through. Moreover, tariff absorption elasticity (in absolute value) and firm productivity are negatively correlated for quality differentiated goods, but positively correlated for quality homogeneous goods. 
On the empirical side, I use the U.S. transaction-level export data and plant-level manufacturing data, and find evidence for the predictions of the model. The firm-level tariff absorption elasticity is 0.87 on average. All products in the sample on average fit the definition of quality differentiated goods, and the tariff absorption elasticity is indeed higher for low productivity firms (1.27) and lower for high productivity firms (0.44). Dividing all products into quality homogeneous goods and quality differentiated goods also results in estimates consistent with model predictions for quality differentiated goods.

The model also has some predictions about the impacts of market size and initial tariff rate on tariff pass-through. However, I did not find empirical evidence for these predictions.

\section{References:}

Bagwell, K. and Staiger, W. (2009), "What Do Trade Negotiators Negotiate about? Empirical Evidence from the World Trade Organization", forthcoming American Economic Review.

Baldwin, R. and Harrigan, J. (2007), "Zeros, Quality and Space: Trade Theory and trade evidence", mimeo, University of Virginia.

Bernard, A. B., Eaton, J., Jensen, J. B., and Kortum, S. (2003), "Plants and Productivity in International Trade", American Economic Review, 94(4), 1268-1290.

Bernard, A. B. and Jensen, J. B. (1995), "Exporters, Jobs, and Wages in US Manufacturing: 1976-1987", Brookings Papers on Economic Activity. Microeconomics, pp.67-119.

Bernard, A. B. and Jensen, J. B. (1999), "Exceptional Exporter Performance: Cause, Effect, or Both?", Journal of International Economics, 47(1), 1-25.

Bernard, A. B., Jensen, J. B., Redding, S., and Schott, P. (2007), "Firms in International Trade", Journal of Economic Perspectives, 21(3), 105-130.

Bernard, A. B., Jensen, J. B., and Schott, P. (2006), "Trade Costs, Firms and Productivity", Journal of Monetary Economics, 53(5), 917-937. 
Bernard, A. B., Jensen, J. B., and Schott, P. (2008), "Importers, Exporters, and Multinationals: A Portrait of Firms in the U.S. that Trades Goods", forthcoming in Dunne, T., Jensen, J. B., and Roberts, M. J., eds Producer Dynamics: New Evidence from Micro Data, University of Chicago Press.

Broda, C., Limão, N., and Weinstein, D. (2008), "Optimal Tariffs and Market Power: The Evidence", American Economic Review, 98(5), 2032-65.

Edgeworth, F. Y. (1894), "The Theory of International Values", Economic Journal, 4, 35-50.

Feenstra, R. (1989), "Symmetric Pass-through of Tariffs and Exchange Rates under Imperfect Competition: An Empirical Test, Journal of International Economics, $27,25-45$.

Feenstra, R. and Weinstein, D. (2010), "Globalization, Markups, and the U.S. Price Level, NBER Working Paper, 15749.

Gervais, A. (2009), "Product Quality and Firm Heterogeneity in International Trade, Working Paper.

Kreinin, M. E. (1961), "Effect of Tariff Changes on the Prices and Volume of Imports", American Economic Review, 51(3), 310-24.

Kugler, M. and Verhoogen, E. (2008), "The Quality-complementarity Hypothesis: Theory and Evidence from Colombia", NBER Working Paper.

Ludema, R. and Mayda, A. M. (2010), "Do Terms-of-trade Effects Matter for Trade Agreements? Evidence from WTO Countries", CEPR Discussion Paper, No. 7695.

Mallick, S. and Marques, H. (2007), "Pass-through of Exchange Rates and Tariffs into Import Prices of India: Currency Depreciation versus Import Liberalization", Working Papers, Center for Globalization Research, No. 3 (September 2007), 287-304.

Mandel, B. (2008), "heterogeneous Firms and Import Quality: Evidence from Transactionlevel Prices", mimeo, University of California at Davis.

Melitz, Marc J. (2003), "The Impact of Trade on Intra-industry Reallocations and Aggregate Industry Productivity", Econometrica, Vol. 71, No. 6, 1695-1725.

Melitz, Marc J. and Ottaviano, Gianmarco I. P. (2008), "Market Size, Trade, and Productivity", Review of Economic Studies, 75, 295-316.

Pierce, J. R. and Schott, P. (2009), "A Concordance Between Ten-Digit U.S. Harmonized System Codes and SIC/NAICS Product Classes and Industries", NBER Working Paper, 15548. 
Rauch, J. (1999). "Networks versus Markets in International Trade". Journal of International Economics, 48, 735.

Roberts, M. and Tybout, Y. (1997), "The Decision to Export in Colombia: An Empirical Model of Entry with Sunk Costs", American Economic Review, pp. 545-564. 
Table 1. Summary Statistics for Two Samples

\begin{tabular}{|c|c|c|c|c|c|c|}
\hline & \multicolumn{3}{|c|}{ Full Sample } & \multicolumn{3}{|c|}{ Sub-sample } \\
\hline No. of HS2 & 85 & & & 85 & & \\
\hline No. of HS6 & 2,005 & & & 1,979 & & \\
\hline No. of HS10 & 2,735 & & & 2,679 & & \\
\hline No. of Firms & 14,404 & & & 13,275 & & \\
\hline No. of Countries & 61 & & & 38 & & \\
\hline$T V_{t-1}$ & $5.28 \times 10^{10}$ & & & $4.26 \times 10^{10}$ & & \\
\hline Variables & No. of Obs. & Mean & Std.Dev. & No. of Obs. & Mean & Std.Dev. \\
\hline$\Delta \ln P_{i f c t}$ & 84,902 & -0.010 & 1.474 & 65,227 & -0.009 & 1.431 \\
\hline$\Delta \tau_{i c t}:$ all & 84,902 & -0.006 & 0.023 & 65,227 & -0.008 & 0.026 \\
\hline$\Delta \tau_{i c t}<0$ & $36,175(43 \%)$ & -0.019 & 0.028 & $34,612(53 \%)$ & -0.019 & 0.028 \\
\hline$\Delta \tau_{i c t}=0$ & $45,125(53 \%)$ & 0 & 0 & $27,047(41 \%)$ & 0 & 0 \\
\hline$\Delta \tau_{i c t}>0$ & $3,602(4 \%)$ & 0.035 & 0.034 & $3,568(6 \%)$ & 0.035 & 0.035 \\
\hline $\operatorname{lnTFP} P_{f(t-1)}$ & 84,902 & 1.888 & 0.577 & 65,227 & 1.889 & 0.581 \\
\hline
\end{tabular}

Notes:

(1) Full Sample: 1997-1998. (Benchmark Sample)

(2) Sub-sample: 1997-1998, countries with large tariff change (higher than 5 percentage points) in at least one HS6 industry. 
Table 2. Countries in the Sub-sample: with Large Tariff Change $\left(\left|\Delta \tau_{i c t}\right|>0.05\right)$ in at Least One HS6 Industry

\begin{tabular}{l|ll|l|ll}
\hline \hline Country & $\begin{array}{l}\text { No. of product-firm } \\
\text {-country-year cells } \\
\text { with }\left|\Delta \tau_{i c t}\right|>0.05\end{array}$ & Ranking & Country & $\begin{array}{l}\text { No. of product-firm } \\
\text {-country-year cells }\end{array}$ & Ranking \\
with $\left|\Delta \tau_{i c t}\right|>0.05$ & \\
\hline Dominica & 457 & 1 & Guatemala & 36 & 21 \\
U.K. & 402 & 2 & Sri Lanka & 32 & 22 \\
Canada & 279 & 3 & Denmark & 29 & 23 \\
Germany & 271 & 4 & Poland & 28 & 24 \\
France & 225 & 5 & Brazil & 25 & 25 \\
Nethelands & 154 & 6 & China & 23 & 26 \\
Phillipines & 154 & Austria & 22 & 27 \\
Italy & 128 & Venezuela & 19 & 28 \\
El Salvador & 111 & 8 & Turkey & 10 & 30 \\
Sweden & 111 & 9 & Greece & 7 & 31 \\
Ireland & 93 & 10 & Argentina & 6 & 32 \\
Egypt & 87 & 11 & Colombia & 6 & 34 \\
Mexico & 76 & Norway & 4 & 35 \\
Belgium & 68 & 12 & Hungary & 3 & 36 \\
Costa Rica & 62 & 13 & Mauritius & 2 & 37 \\
Panama & 61 & 14 & Uruguay & 2 & 38 \\
Honduras & 53 & 15 & Ecuador & 2 & \\
Finland & 46 & 16 & Madagascar & 2 & \\
Japan & 45 & 17 & & & \\
Spain & 43 & 18 & & & \\
\hline \hline
\end{tabular}


Table 3. Tariff Absorption: Benchmark Sample, All Products

\begin{tabular}{|c|c|c|c|c|c|c|}
\hline $\begin{array}{l}\text { Dependent Variable } \\
\text { Regressors }\end{array}$ & $\begin{array}{l}\ln P_{i f c(t-1)}^{*} \\
(1)\end{array}$ & $\begin{array}{l}\Delta P_{i f c t}^{*} \\
(2)\end{array}$ & $\begin{array}{l}\Delta \ln P_{i f c t}^{*} \\
(3)\end{array}$ & $\begin{array}{l}\Delta \ln P_{i f c t}^{*} \\
(4)\end{array}$ & $\begin{array}{l}\Delta \ln P_{i f c t}^{*} \\
(5)\end{array}$ & $\begin{array}{l}\Delta \ln P_{i f c t}^{*} \\
(6)\end{array}$ \\
\hline$\Delta \tau_{i c t}$ & & $\begin{array}{l}-516 \\
(33000)\end{array}$ & & & & \\
\hline $\operatorname{lnTFP} P_{f(t-1)}$ & $\begin{array}{l}0.06^{* * *} \\
(0.01)\end{array}$ & $\begin{array}{l}1,500^{* * *} \\
(548)\end{array}$ & & & & \\
\hline$\Delta \tau_{i c t} \times \ln T F P_{f(t-1)}$ & & $\begin{array}{l}-1700 \\
(16000)\end{array}$ & & & & \\
\hline$\Delta \ln \left(1+\tau_{i c t}\right)$ & & & $\begin{array}{l}-0.87^{* *} \\
(0.35)\end{array}$ & $\begin{array}{l}-1.27^{* * * *} \\
(0.42)\end{array}$ & $\begin{array}{l}-0.89^{* *} \\
(0.38)\end{array}$ & $\begin{array}{l}-4.96 \\
(5.1)\end{array}$ \\
\hline$T F P H_{f(t-1)}$ & & & & $\begin{array}{l}0.02^{* *} \\
(0.01)\end{array}$ & $\begin{array}{l}0.02^{* *} \\
(0.01)\end{array}$ & $\begin{array}{l}0.02^{* *} \\
(0.01)\end{array}$ \\
\hline$\Delta \ln \left(1+\tau_{i c t}\right) \times T F P H_{f(t-1)}$ & & & & $\begin{array}{l}0.83^{*} \\
(0.50)\end{array}$ & $\begin{array}{l}0.84^{*} \\
(0.50)\end{array}$ & $\begin{array}{l}0.83^{*} \\
(0.50)\end{array}$ \\
\hline$\Delta \ln X R_{c(t-1)}$ & & & & & $\begin{array}{l}0.03 \\
(0.07)\end{array}$ & $\begin{array}{l}0.03 \\
(0.07)\end{array}$ \\
\hline$\Delta \ln G D P_{c t}$ & & & & & $\begin{array}{l}-0.0002 \\
(0.05)\end{array}$ & $\begin{array}{l}-0.01 \\
(0.05)\end{array}$ \\
\hline $\ln \left(1+\tau_{i c(t-1)}\right)$ & & & & & & $\begin{array}{l}0.12 \\
(0.12)\end{array}$ \\
\hline $\ln G D P_{c(t-1)}$ & & & & & & $\begin{array}{l}0.0005 \\
(0.004)\end{array}$ \\
\hline$\Delta \ln \left(1+\tau_{i c t}\right) \times \ln \left(1+\tau_{i c(t-1)}\right)$ & & & & & & $\begin{array}{l}4.12 \\
(3.42)\end{array}$ \\
\hline$\Delta \ln \left(1+\tau_{i c t}\right) \times \ln G D P_{c(t-1)}$ & & & & & & $\begin{array}{l}0.14 \\
(0.19)\end{array}$ \\
\hline Fixed Effects & $\begin{array}{l}\text { product } \\
\times \text { country }\end{array}$ & $\begin{array}{l}\text { product } \\
+ \text { country }\end{array}$ & $\begin{array}{l}\text { product } \\
+ \text { country }\end{array}$ & $\begin{array}{l}\text { product } \\
+ \text { country }\end{array}$ & product & product \\
\hline $\begin{array}{l}\text { No. of Obs. } \\
R^{2}\end{array}$ & $\begin{array}{l}84,902 \\
0.81\end{array}$ & $\begin{array}{l}84,902 \\
0.14\end{array}$ & $\begin{array}{l}84,902 \\
0.03\end{array}$ & $\begin{array}{l}84,902 \\
0.03\end{array}$ & $\begin{array}{l}84,902 \\
0.03\end{array}$ & $\begin{array}{l}84,902 \\
0.03\end{array}$ \\
\hline
\end{tabular}

Notes: Standard errors are reported in parentheses. *, **, and *** denote the 10, 5, and 1 percent of significance levels. 
Table 4. Tariff Absorption: Countries with Large Tariff Change, All Products

\begin{tabular}{|c|c|c|c|c|c|c|}
\hline $\begin{array}{l}\text { Dependent Variable } \\
\text { Regressors }\end{array}$ & $\begin{array}{l}\ln P_{i f c(t-1)}^{*} \\
(1)\end{array}$ & $\begin{array}{l}\Delta P_{i f c t}^{*} \\
(2)\end{array}$ & $\begin{array}{l}\Delta \ln P_{i f c t}^{*} \\
(3)\end{array}$ & $\begin{array}{l}\ln P_{i f c t}^{*} \\
(4)\end{array}$ & $\begin{array}{l}\ln P_{i f c t}^{*} \\
(5)\end{array}$ & $\begin{array}{l}\Delta \ln P_{i f c t}^{*} \\
(6)\end{array}$ \\
\hline$\Delta \tau_{i c t}$ & & $\begin{array}{l}-2,200 \\
(38000)\end{array}$ & & & & \\
\hline $\operatorname{lnTFP} P_{f(t-1)}$ & $\begin{array}{l}0.05^{* * *} \\
(0.01)\end{array}$ & $\begin{array}{l}1,800^{* *} \\
(695)\end{array}$ & & & & \\
\hline$\Delta \tau_{i c t} \times \ln T F P_{f(t-1)}$ & & $\begin{array}{l}-620 \\
(973)\end{array}$ & & & & \\
\hline$\Delta \ln \left(1+\tau_{i c t}\right)$ & & & $\begin{array}{l}-0.65^{*} \\
(0.35)\end{array}$ & $\begin{array}{l}-1.08^{* *} \\
(0.43)\end{array}$ & $\begin{array}{l}-0.75^{* *} \\
(0.38)\end{array}$ & $\begin{array}{l}-6.96 \\
(5.3)\end{array}$ \\
\hline$T F P H_{f(t-1)}$ & & & & $\begin{array}{l}0.03^{* * *} \\
(0.01)\end{array}$ & $\begin{array}{l}0.03^{* *} \\
(0.01)\end{array}$ & $\begin{array}{l}0.03^{* *} \\
(0.01)\end{array}$ \\
\hline$\Delta \ln \left(1+\tau_{i c t}\right) \times T F P H_{f(t-1)}$ & & & & $\begin{array}{l}0.90^{*} \\
(0.50)\end{array}$ & $\begin{array}{l}0.90^{*} \\
(0.50)\end{array}$ & $\begin{array}{l}0.90^{*} \\
(0.50)\end{array}$ \\
\hline$\Delta \ln X R_{c(t-1)}$ & & & & & $\begin{array}{l}0.04 \\
(0.08)\end{array}$ & $\begin{array}{l}0.04 \\
(0.08)\end{array}$ \\
\hline$\Delta \ln G D P_{c t}$ & & & & & $\begin{array}{l}-0.07 \\
(0.10)\end{array}$ & $\begin{array}{l}-0.07 \\
(0.10)\end{array}$ \\
\hline $\ln \left(1+\tau_{i c(t-1)}\right)$ & & & & & & $\begin{array}{l}0.03 \\
(0.15)\end{array}$ \\
\hline $\ln G D P_{c(t-1)}$ & & & & & & $\begin{array}{l}0.001 \\
(0.006)\end{array}$ \\
\hline$\Delta \ln \left(1+\tau_{i c t}\right) \times \ln \left(1+\tau_{i c(t-1)}\right)$ & & & & & & $\begin{array}{l}3.23 \\
(3.62)\end{array}$ \\
\hline$\Delta \ln \left(1+\tau_{i c t}\right) \times \ln G D P_{c(t-1)}$ & & & & & & $\begin{array}{l}0.22 \\
(0.19)\end{array}$ \\
\hline Fixed Effects & $\begin{array}{l}\text { product } \\
\times \text { country }\end{array}$ & $\begin{array}{l}\text { product } \\
+ \text { country }\end{array}$ & $\begin{array}{l}\text { product } \\
+ \text { country }\end{array}$ & $\begin{array}{l}\text { product } \\
+ \text { country }\end{array}$ & product & product \\
\hline $\begin{array}{l}\text { No. of Obs. } \\
R^{2}\end{array}$ & $\begin{array}{l}65,227 \\
0.82\end{array}$ & $\begin{array}{l}65,227 \\
0.14\end{array}$ & $\begin{array}{l}65,227 \\
0.04\end{array}$ & $\begin{array}{l}65,227 \\
0.04\end{array}$ & $\begin{array}{l}865,227 \\
0.04\end{array}$ & $\begin{array}{l}65,227 \\
0.04\end{array}$ \\
\hline
\end{tabular}

Notes: Standard errors are reported in parentheses. *, **, and *** denote the 10, 5, and 1 percent of significance levels. 
Table 5. Tariff Absorption: Benchmark Sample, Commodities

\begin{tabular}{|c|c|c|c|c|c|c|}
\hline $\begin{array}{l}\text { Dependent Variable } \\
\text { Regressors }\end{array}$ & $\begin{array}{l}\ln P_{i f c(t-1)}^{*} \\
(1)\end{array}$ & $\begin{array}{l}\Delta P_{i f c t}^{*} \\
(2)\end{array}$ & $\begin{array}{l}\ln P_{i f c t}^{*} \\
(3)\end{array}$ & $\begin{array}{l}\Delta \ln P_{i f c t}^{*} \\
(4)\end{array}$ & $\begin{array}{l}\Delta \ln P_{i f c t}^{*} \\
(5)\end{array}$ & $\begin{array}{l}\Delta \ln P_{i f c t}^{*} \\
(6)\end{array}$ \\
\hline$\Delta \tau_{i c t}$ & & $\begin{array}{l}231 \\
(7,700)\end{array}$ & & & & \\
\hline $\operatorname{lnTFP} P_{f(t-1)}$ & $\begin{array}{l}0.23 \\
(0.15)\end{array}$ & $\begin{array}{l}-37.4 \\
(207)\end{array}$ & & & & \\
\hline$\Delta \tau_{i c t} \times \operatorname{lnTFP} P_{f(t-1)}$ & & $\begin{array}{l}47.5 \\
(6,100)\end{array}$ & & & & \\
\hline$\Delta \ln \left(1+\tau_{i c t}\right)$ & & & $\begin{array}{l}-1.21^{* *} \\
(0.60)\end{array}$ & $\begin{array}{l}-0.73 \\
(0.72)\end{array}$ & $\begin{array}{l}-0.67 \\
(0.65)\end{array}$ & $\begin{array}{l}22.4^{*} \\
(13.6)\end{array}$ \\
\hline$T F P H_{f(t-1)}$ & & & & $\begin{array}{l}0.007 \\
(0.02)\end{array}$ & $\begin{array}{l}0.008 \\
(0.02)\end{array}$ & $\begin{array}{l}0.008 \\
(0.02)\end{array}$ \\
\hline$\Delta \ln \left(1+\tau_{i c t}\right) \times T F P H_{f(t-1)}$ & & & & $\begin{array}{l}-1.14 \\
(0.92)\end{array}$ & $\begin{array}{l}-1.10 \\
(0.91)\end{array}$ & $\begin{array}{l}-1.18 \\
(0.92)\end{array}$ \\
\hline$\Delta \ln X R_{c(t-1)}$ & & & & & $\begin{array}{l}0.19 \\
(0.17)\end{array}$ & $\begin{array}{l}0.17 \\
(0.18)\end{array}$ \\
\hline$\Delta \ln G D P_{c t}$ & & & & & $\begin{array}{l}0.16 \\
(0.10)\end{array}$ & $\begin{array}{l}0.15 \\
(0.10)\end{array}$ \\
\hline $\ln \left(1+\tau_{i c(t-1)}\right)$ & & & & & & $\begin{array}{l}0.11 \\
(0.18)\end{array}$ \\
\hline $\ln G D P_{c(t-1)}$ & & & & & & $\begin{array}{l}-0.01 \\
(0.01)\end{array}$ \\
\hline$\Delta \ln \left(1+\tau_{i c t}\right) \times \ln \left(1+\tau_{i c(t-1)}\right)$ & & & & & & $\begin{array}{l}-3.41 \\
(8.16)\end{array}$ \\
\hline$\Delta \ln \left(1+\tau_{i c t}\right) \times \ln G D P_{c(t-1)}$ & & & & & & $\begin{array}{c}-0.86^{*} \\
(0.49)\end{array}$ \\
\hline Fixed Effects & $\begin{array}{l}\text { product } \\
\times \text { country }\end{array}$ & $\begin{array}{l}\text { product } \\
+ \text { country }\end{array}$ & $\begin{array}{l}\text { product } \\
+ \text { country }\end{array}$ & $\begin{array}{l}\text { product } \\
+ \text { country }\end{array}$ & product & product \\
\hline $\begin{array}{l}\text { No. of Obs. } \\
R^{2}\end{array}$ & $\begin{array}{l}6,171 \\
0.86\end{array}$ & $\begin{array}{l}6,171 \\
0.07\end{array}$ & $\begin{array}{l}6,171 \\
0.08\end{array}$ & $\begin{array}{l}6,171 \\
0.08\end{array}$ & $\begin{array}{l}6,171 \\
0.07\end{array}$ & $\begin{array}{l}6,171 \\
0.07\end{array}$ \\
\hline
\end{tabular}

Notes: Standard errors are reported in parentheses. *, **, and *** denote the 10, 5, and 1 percent of significance levels. 
Table 6. Tariff Absorption: Benchmark Sample, Differentiated Products - In terms of the Rauch Classification

\begin{tabular}{|c|c|c|c|c|c|c|}
\hline $\begin{array}{l}\text { Dependent Variable } \\
\text { Regressors }\end{array}$ & $\begin{array}{l}\ln P_{i f c(t-1)}^{*} \\
(1)\end{array}$ & $\begin{array}{l}\Delta P_{i f c t}^{*} \\
(2)\end{array}$ & $\begin{array}{l}\ln P_{i f c t}^{*} \\
(3)\end{array}$ & $\begin{array}{l}\Delta \ln P_{i f c t}^{*} \\
(4)\end{array}$ & $\begin{array}{l}\Delta \ln P_{i f c t}^{*} \\
(5)\end{array}$ & $\begin{array}{l}\Delta \ln P_{i f c t}^{*} \\
(6)\end{array}$ \\
\hline$\Delta \tau_{i c t}$ & & $\begin{array}{l}-1,300 \\
(40,000)\end{array}$ & & & & \\
\hline $\operatorname{lnTFP} P_{f(t-1)}$ & $\begin{array}{l}0.05^{* * *} \\
(0.01)\end{array}$ & $\begin{array}{l}-1,600 \\
(592)\end{array}$ & & & & \\
\hline$\Delta \tau_{i c t} \times \ln T F P_{f(t-1)}$ & & $\begin{array}{l}-1,300 \\
(18,000)\end{array}$ & & & & \\
\hline$\Delta \ln \left(1+\tau_{i c t}\right)$ & & & $\begin{array}{l}-0.80^{* *} \\
(0.38)\end{array}$ & $\begin{array}{l}-1.30^{* * *} \\
(0.46)\end{array}$ & $\begin{array}{l}-0.93^{* *} \\
(0.41)\end{array}$ & $\begin{array}{l}-6.73 \\
(5.37)\end{array}$ \\
\hline$T F P H_{f(t-1)}$ & & & & $\begin{array}{l}0.02^{* *} \\
(0.01)\end{array}$ & $\begin{array}{l}0.2^{* *} \\
(0.01)\end{array}$ & $\begin{array}{l}0.02^{* *} \\
(0.01)\end{array}$ \\
\hline$\Delta \ln \left(1+\tau_{i c t}\right) \times T F P H_{f(t-1)}$ & & & & $\begin{array}{l}1.04^{*} \\
(0.54)\end{array}$ & $\begin{array}{l}1.05^{*} \\
(0.54)\end{array}$ & $\begin{array}{l}1.04^{*} \\
\left(0.54^{*}\right)\end{array}$ \\
\hline$\Delta \ln X R_{c(t-1)}$ & & & & & $\begin{array}{l}0.03 \\
(0.07)\end{array}$ & $\begin{array}{l}0.02 \\
(0.08)\end{array}$ \\
\hline$\Delta \ln G D P_{c t}$ & & & & & $\begin{array}{l}-0.02 \\
(0.06)\end{array}$ & $\begin{array}{l}-0.03 \\
(0.06)\end{array}$ \\
\hline $\ln \left(1+\tau_{i c(t-1)}\right)$ & & & & & & $\begin{array}{l}0.13 \\
(0.13)\end{array}$ \\
\hline $\ln G D P_{c(t-1)}$ & & & & & & $\begin{array}{l}0.001 \\
(0.005)\end{array}$ \\
\hline$\Delta \ln \left(1+\tau_{i c t}\right) \times \ln \left(1+\tau_{i c(t-1)}\right)$ & & & & & & $\begin{array}{l}4.37 \\
(3.62)\end{array}$ \\
\hline$\Delta \ln \left(1+\tau_{i c t}\right) \times \ln G D P_{c(t-1)}$ & & & & & & $\begin{array}{l}0.20 \\
(0.20)\end{array}$ \\
\hline Fixed Effects & $\begin{array}{l}\text { product } \\
\times \text { country }\end{array}$ & $\begin{array}{l}\text { product } \\
\text { +country }\end{array}$ & $\begin{array}{l}\text { product } \\
\text { +country }\end{array}$ & $\begin{array}{l}\text { product } \\
\text { +country }\end{array}$ & product & product \\
\hline $\begin{array}{l}\text { No. of Obs. } \\
R^{2}\end{array}$ & $\begin{array}{l}78,731 \\
0.80\end{array}$ & $\begin{array}{l}78,731 \\
0.14\end{array}$ & $\begin{array}{l}78,731 \\
0.03\end{array}$ & $\begin{array}{l}78,731 \\
0.03\end{array}$ & $\begin{array}{l}78,731 \\
0.03\end{array}$ & $\begin{array}{l}78,731 \\
0.03\end{array}$ \\
\hline
\end{tabular}

Notes: Standard errors are reported in parentheses. ****, and *** denote the 10, 5, and 1 percent of significance levels. 
Table 7. Tariff Absorption: Benchmark Sample, Quality Homogeneous Goods - With Low R\&D/Sales Ratios

\begin{tabular}{|c|c|c|c|c|c|c|}
\hline $\begin{array}{l}\text { Dependent Variable } \\
\text { Regressors }\end{array}$ & $\begin{array}{l}\ln P_{i f c(t-1)}^{*} \\
(1)\end{array}$ & $\begin{array}{l}\Delta P_{i f c t}^{*} \\
(2)\end{array}$ & $\begin{array}{l}\ln P_{i f c t}^{*} \\
(3)\end{array}$ & $\begin{array}{l}\Delta \ln P_{i f c t}^{*} \\
(4)\end{array}$ & $\begin{array}{l}\ln P_{i f c t}^{*} \\
(5)\end{array}$ & $\begin{array}{l}\ln P_{i f c t}^{*} \\
(6)\end{array}$ \\
\hline$\Delta \tau_{i c t}$ & & $\begin{array}{l}-38 \\
(528)\end{array}$ & & & & \\
\hline $\ln T F P_{f(t-1)}$ & $\begin{array}{l}0.24 \\
(0.25)\end{array}$ & $\begin{array}{l}-0.86 \\
(19)\end{array}$ & & & & \\
\hline$\Delta \tau_{i c t} \times \ln T F P_{f(t-1)}$ & & $\begin{array}{l}-47 \\
(550)\end{array}$ & & & & \\
\hline$\Delta \ln \left(1+\tau_{i c t}\right)$ & & & $\begin{array}{l}-0.60 \\
(0.49)\end{array}$ & $\begin{array}{l}-0.64 \\
(0.56)\end{array}$ & $\begin{array}{l}-0.43 \\
(0.43)\end{array}$ & $\begin{array}{l}3.30 \\
(7.26)\end{array}$ \\
\hline$T F P H_{f(t-1)}$ & & & & $\begin{array}{l}0.006 \\
(0.017)\end{array}$ & $\begin{array}{l}0.006 \\
(0.017)\end{array}$ & $\begin{array}{l}0.006 \\
(0.017)\end{array}$ \\
\hline$\Delta \ln \left(1+\tau_{i c t}\right) \times T F P H_{f(t-1)}$ & & & & $\begin{array}{l}0.08 \\
(0.59)\end{array}$ & $\begin{array}{l}0.10 \\
(0.59)\end{array}$ & $\begin{array}{l}0.11 \\
(0.59)\end{array}$ \\
\hline$\Delta \ln X R_{c(t-1)}$ & & & & & $\begin{array}{l}0.32^{* *} \\
(0.15)\end{array}$ & $\begin{array}{l}0.33^{* *} \\
(0.15)\end{array}$ \\
\hline$\Delta \ln G D P_{c t}$ & & & & & $\begin{array}{l}0.05 \\
(0.10)\end{array}$ & $\begin{array}{l}0.05 \\
(0.10)\end{array}$ \\
\hline $\ln \left(1+\tau_{i c(t-1)}\right)$ & & & & & & $\begin{array}{l}0.02 \\
(0.16)\end{array}$ \\
\hline $\ln G D P_{c(t-1)}$ & & & & & & $\begin{array}{l}-0.002 \\
(0.008)\end{array}$ \\
\hline$\Delta \ln \left(1+\tau_{i c t}\right) \times \ln \left(1+\tau_{i c(t-1)}\right)$ & & & & & & $\begin{array}{l}3.97 \\
(4.49)\end{array}$ \\
\hline$\Delta \ln \left(1+\tau_{i c t}\right) \times \ln G D P_{c(t-1)}$ & & & & & & $\begin{array}{l}-0.19 \\
(0.28)\end{array}$ \\
\hline Fixed Effects & $\begin{array}{l}\text { product } \\
\times \text { country }\end{array}$ & $\begin{array}{l}\text { product } \\
+ \text { country }\end{array}$ & $\begin{array}{l}\text { product } \\
+ \text { country }\end{array}$ & $\begin{array}{l}\text { product } \\
+ \text { country }\end{array}$ & product & product \\
\hline No. of Obs. & 15,408 & 15,408 & 15,408 & 15,408 & 15,408 & 44,167 \\
\hline$R^{2}$ & 0.82 & 0.01 & 0.04 & 0.04 & 0.04 & 0.04 \\
\hline
\end{tabular}

Notes: Standard errors are reported in parentheses. *, **, and *** denote the 10, 5 , and 1 percent of significance levels. 
Table 8. Tariff Absorption: Benchmark Sample, Quality Differentiated Goods - With High R\&D/Sales Ratios

\begin{tabular}{|c|c|c|c|c|c|c|}
\hline $\begin{array}{l}\text { Dependent Variable } \\
\text { Regressors }\end{array}$ & $\begin{array}{l}\ln P_{i f c(t-1)}^{*} \\
(1)\end{array}$ & $\begin{array}{l}\Delta P_{i f c t}^{*} \\
(2)\end{array}$ & $\begin{array}{l}\ln P_{i f c t}^{*} \\
(3)\end{array}$ & $\begin{array}{l}\ln P_{i f c t}^{*} \\
(4)\end{array}$ & $\begin{array}{l}\ln P_{i f c t}^{*} \\
(5)\end{array}$ & $\begin{array}{l}\ln P_{i f c t}^{*} \\
(6)\end{array}$ \\
\hline$\Delta \tau_{i c t}$ & & $\begin{array}{l}-3,900 \\
(24,000)\end{array}$ & & & & \\
\hline $\ln T F P_{f(t-1)}$ & $\begin{array}{l}0.03^{* *} \\
(0.01)\end{array}$ & $\begin{array}{l}1,500^{* *} \\
(609)\end{array}$ & & & & \\
\hline$\Delta \tau_{i c t} \times \ln T F P_{f(t-1)}$ & & $\begin{array}{l}-3,400 \\
(29,000)\end{array}$ & & & & \\
\hline$\Delta \ln \left(1+\tau_{i c t}\right)$ & & & $\begin{array}{l}-1.01^{* *} \\
(0.46)\end{array}$ & $\begin{array}{l}-1.60^{* * *} \\
(0.56)\end{array}$ & $\begin{array}{l}-1.15^{* *} \\
(0.50)\end{array}$ & $\begin{array}{l}-8.90 \\
(7.10)\end{array}$ \\
\hline$T F P H_{f(t-1)}$ & & & & $\begin{array}{l}0.03^{* *} \\
(0.01)\end{array}$ & $\begin{array}{l}0.03^{* *} \\
(0.01)\end{array}$ & $\begin{array}{l}0.03^{* *} \\
(0.01)\end{array}$ \\
\hline$\Delta \ln \left(1+\tau_{i c t}\right) \times T F P H_{f(t-1)}$ & & & & $\begin{array}{l}1.22^{*} \\
(0.66)\end{array}$ & $\begin{array}{l}1.23^{*} \\
(0.66)\end{array}$ & $\begin{array}{l}1.23^{*} \\
(0.66)\end{array}$ \\
\hline$\Delta \ln X R_{c(t-1)}$ & & & & & $\begin{array}{l}-0.003 \\
(0.081)\end{array}$ & $\begin{array}{l}-0.013 \\
(0.082)\end{array}$ \\
\hline$\Delta \ln G D P_{c t}$ & & & & & $\begin{array}{c}-0.008 \\
(0.06)\end{array}$ & $\begin{array}{l}-0.018 \\
(0.06)\end{array}$ \\
\hline $\ln \left(1+\tau_{i c(t-1)}\right)$ & & & & & & $\begin{array}{l}0.13 \\
(0.15)\end{array}$ \\
\hline $\ln G D P_{c(t-1)}$ & & & & & & $\begin{array}{l}0.002 \\
(0.005)\end{array}$ \\
\hline$\Delta \ln \left(1+\tau_{i c t}\right) \times \ln \left(1+\tau_{i c(t-1)}\right)$ & & & & & & $\begin{array}{l}3.52 \\
(4.38)\end{array}$ \\
\hline$\Delta \ln \left(1+\tau_{i c t}\right) \times \ln G D P_{c(t-1)}$ & & & & & & $\begin{array}{l}0.28 \\
(0.26)\end{array}$ \\
\hline Fixed Effects & $\begin{array}{l}\text { product } \\
\times \text { country }\end{array}$ & $\begin{array}{l}\text { product } \\
+ \text { country }\end{array}$ & $\begin{array}{l}\text { product } \\
+ \text { country }\end{array}$ & $\begin{array}{l}\text { product } \\
+ \text { country }\end{array}$ & product & product \\
\hline $\begin{array}{l}\text { No. of Obs. } \\
R^{2}\end{array}$ & $\begin{array}{l}69,494 \\
0.79\end{array}$ & $\begin{array}{l}69,494 \\
0.14\end{array}$ & $\begin{array}{l}69,494 \\
0.03\end{array}$ & $\begin{array}{l}69,494 \\
0.03\end{array}$ & $\begin{array}{l}69,494 \\
0.03\end{array}$ & $\begin{array}{l}69,494 \\
0.03\end{array}$ \\
\hline
\end{tabular}

Notes: Standard errors are reported in parentheses. *, **, and *** denote the 10, 5 , and 1 percent of significance levels. 